\title{
A 68 ka precipitation record from the hyperarid core of the Atacama Desert in northern Chile
}

Julia L. Diederich ${ }^{1}$, Volker Wennrich ${ }^{1}$, Roberto Bao ${ }^{2}$, Christoph Büttner ${ }^{3}$, Andreas Bolten ${ }^{4}$, Dominik Brill ${ }^{4}$, Stefan Buske ${ }^{3}$, Eduardo Campos ${ }^{5}$, Emma Fernández-Galego ${ }^{1}$, Peggy Gödickmeier $^{3}$, Lukas Ninnemann ${ }^{3}$, Mark Reyers ${ }^{6}$, Benedikt Ritter ${ }^{1}$, Laura Ritterbach ${ }^{1}$, Christian Rolf ${ }^{7}$, Stephanie Scheidt ${ }^{1}$, Tibor J. Dunai ${ }^{1}$, Martin Melles ${ }^{1}$

${ }^{1}$ Institute of Geology and Mineralogy, University of Cologne, Germany

${ }^{2}$ Centro de Investigacións Científicas Avanzadas (CICA), Facultade de Ciencias, Universidade da Coruña, Spain

${ }^{3}$ Institute of Geophysics and Geoinformatics, TU Bergakademie Freiberg, Germany

${ }^{4}$ Institute of Geography, University of Cologne, Germany

${ }^{5}$ Universidad Católica del Norte, Antofagasta, Chile

${ }^{6}$ Institute of Geophysics and Meteorology, University of Cologne, Germany

${ }^{7}$ Leibniz Institute for Applied Geophysics (LIAG), Hannover, Germany

Corresponding author: Julia L. Diederich

Institute of Geology and Mineralogy
University of Cologne
Zuelpicher Str. 49a
D-50674 Koeln
Germany
diederich.julia@uni-koeln.de

(C) 2019. This manuscript version is made available under the CC Attribution-NonCommercialNoDerivatives 4.0 International license: http://creativecommons.org/licenses/by-nc-nd/4.0.

How to cite: Diederich, J.L., Wennrich, V., Bao, R., Büttner, C., Bolten, A., Brill, D., Buske, S., Campos, E., Fernández-Galego, E., Gödickmeier, P., Ninnemann, L., Reyers, M., Ritter, B., Ritterbach, L., Rolf, C., Scheidt, S., Dunai, T.J., Melles, M., 2020. A 68 ka precipitation record from the hyperarid core of the Atacama Desert in northern Chile. Glob. Planet. Change 184, 103054. doi:10.1016/J.GLOPLACHA.2019.103054 


\begin{abstract}
The Atacama Desert in northern Chile is one of the driest deserts on Earth. Hyperaridity persists at least since the Miocene and was punctuated by pluvial phases. However, very little is known about the timing, regional spread and intensities of precipitation changes. Here, we present a new precipitation record from a sedimentary sequence recovered in a tectonically blocked endorheic basin that is located in the hyperarid core of the Atacama Desert. The chronostratigraphic framework of the record is given by a multi-disciplinary dating approach, suggesting an age of ca. $68 \mathrm{ka}$ BP for the core base. The sequence consists of three sediment types, whose sedimentological and geochemical characteristics suggest different depositional processes that reflect different degrees in humidity. First, particularly fine-grained sediments with high clastic but low calcium sulfate and carbonate contents reflect a particularly dry climate with only sporadic precipitation events and fluvial supply via channel systems. Second, more coarse-grained sediments with lower clastic and higher calcium sulfate and carbonate contents reflect more moist conditions with stronger precipitation events that lead to fluvial activity not restricted to the channels but involving the slopes and plains in the catchment. Third, normally graded layers with an equally high proportion of calcium sulfate and carbonate reflect occasional high-precipitation events that caused sediment supply also from most distant parts of the catchment via severe flash floods. The sedimentary succession suggests that precipitation changes took place on orbital but also on millennial time scales. Rather moist periods occurred during most of MIS 2 , several shorter periods within MIS 3 and parts of MIS 4. Comparison of the findings from the Huara record with selected climate records from continental and marine sites in South America suggests a strong precipitation heterogeneity across the Atacama. This heterogeneity is caused by pronounced differences in the dominating climate patterns and a shift from predominant summer rain in the north to winter rain in the south. Precipitation supply to the Huara clay plan is controlled by the atmospheric circulation rather than the surface temperature of the adjacent ocean.
\end{abstract}

\title{
Keywords
}

Atacama; Hyperaridity; Endorheic basin; Paleoclimate; Precipitation history 


\section{Introduction}

The Atacama Desert of northern Chile (Fig. 1A and B) is assumed to be one of the oldest hyperarid deserts on Earth (Dunai et al., 2005; Evenstar et al., 2017), with hyperaridity likely dating back to the Eocene-Oligocene. The onset of hyperaridity is linked to the successive opening of the Drake Passage since ca. 50 Ma that caused a change in the global ocean circulation and the establishment of the Peru-Chile Current system (Cristini et al., 2012). The early hyperaridity is partly confirmed by studies of terrestrial cosmogenic nuclides (Dunai et al., 2005; Evenstar et al., 2017; Ritter et al., 2018) and the cessation of supergene orebodies (Alpers and Brimhall, 1988; Sillitoe and McKee, 1996), which all suggest arid to hyperarid climate conditions in the Atacama region at least since the early Miocene. For the late Miocene to Pleistocene, sedimentary records of the Central Depression to the east of the Coastal Cordillera (Fig. 1A; Bobst et al., 2001; Hartley and Chong, 2002; Pfeiffer et al., 2018; Sáez et al., 2012) and the Altiplano (Baker et al., 2001; Fritz et al., 2004; Nunnery et al., 2018) indicate severe variations in the intensity of aridity.

For the past $500 \mathrm{kyrs}$, long-term fluctuations in aridity of the Atacama Desert are indicated by marine records of the adjacent Pacific Ocean (Lamy et al., 1998; Rincón-Martínez et al., 2010; Stuut and Lamy, 2004). On a shorter timescale, paleowetland stratigraphies and plant fossils from rodent middens in the Central Atacama and the Andean Precordillera reflect shifts to less arid climate conditions over the last approx. 50 ka (Betancourt et al., 2000; De Porras et al., 2017; Díaz et al., 2012; Maldonado et al., 2005; Mujica et al., 2015; Rech et al., 2002). These vegetation changes are traced back to interhemispheric teleconnections by triggering variations in the intensity of the South American Summer Monsoon (SASM) (Betancourt et al., 2000; Latorre et al., 2002). In the hyperarid core of the Coastal Cordillera, defined by precipitation below $2 \mathrm{~mm} / \mathrm{yr}$ (Houston, 2006b), the only record of moisture changes is derived from an endorheic clay pan to the south of the Rio Loa ('PAG' clay pan; Fig. 1A; Ritter et al., 2019). The results reflect fluctuations in local runoff in the Coastal Cordillera of the past ca. $215 \mathrm{ka} \mathrm{BP}$, suggesting increased precipitation during warmer intervals of Marine Isotope Stages (MIS) 7 and 5, whereas reduced precipitation is concordant with colder conditions during MIS 6 as well as MIS 4 to 1.

Within the framework of a larger project to investigate the precipitation history and variability in the hyperarid core of the Atacama Desert, several clay pans in the Coastal Cordillera along a latitudinal gradient $\left(20^{\circ}-24.5^{\circ}\right.$ S; e.g., Huara, PAG) were investigated. Due to their position in the Coastal Cordillera, these clay pans are hydrologically disconnected from the runoff signal of the Altiplano, and thus, record only the regional precipitation. 
Here, we provide the first precipitation record from the northern part of the hyperarid core. The $4.1 \mathrm{~m}$ long sediment record originates from the so-called 'Huara' clay pan that receives only local precipitation and dates back to ca. $68 \mathrm{ka}$. Based upon a multi-disciplinary investigation of the sediment succession, several pluvial phases of variable duration and intensity are detected. The comparison with the results derived from the clay pan further south (Ritter et al., 2019) as well as with marine and terrestrial paleoenvironmental data to the west and east of the Atacama Desert, respectively, provide new insights into the homogeneities and heterogeneities on the precipitation patterns in the Atacama Desert and shed light on the climatic drivers of moisture sources.

\section{Site information}

The aridity of the Atacama Desert is governed by several factors. The large-scale atmospheric subsidence produces dry and stable conditions, creating a surface anticyclone over the subtropical southeast Pacific that interferes mid-latitude disturbances (Garreaud et al., 2003; Takahashi and Battisti, 2007). Southerly winds generated by the anticyclone promote the costal upwelling system and the transport of cold waters from higher latitudes via the northward running Humboldt Current along the Chilean coast (Houston and Hartley, 2003; Thiel et al., 2007). As a result, moisture capacity of the onshore winds is reduced, which causes a sustained inversion layer, in which the Pacific moisture is trapped below ca. $1000 \mathrm{~m}$ above sea level (a.s.l.) (Houston, 2006b; Rutllant et al., 2013) and creates a persistent deck of stratus clouds (Cereceda et al., 2008; Rutllant et al., 2003; Takahashi and Battisti, 2007). The hyperarid climate in the Atacama Desert is enhanced by the continental effect (distance to Atlantic), and by the distinct rain-shadow effect of the Andean mountain range, which hinders moisture transfer coming from the Amazon Basin (Garreaud et al., 2010; Garreaud et al., 2009; Houston and Hartley, 2003; Rech et al., 2010; Takahashi and Battisti, 2007). The dry climate conditions are furthermore amplified by the high evaporation rates in most regions of the Atacama Desert (Houston, 2006a).

\subsection{Precipitation pattern}

In the Atacama Desert, the winter rainfall is characterized by northward and eastward moving frontal systems, which originate from cyclones of the extra-tropical Pacific (Vuille, 1999). During summer, intense convection over the South American continent contribute to the formation of the Bolivian High. The Bolivian High is modulated by Rossby waves, and a southward displacement of this system is associated to anomalous strong easterly winds over the central Andes (Garreaud et al., 2003), resulting in enhanced moisture transport from the Amazon Basin to the Altiplano (Galewsky and Samuels-Crow, 2015). Due to the topographic features a rain shadow develops over the Precordillera, the Central Depression 
and the Coastal Cordillera (Houston, 2006b). As a consequence, the Altiplano experiences a mean annual precipitation of $300 \mathrm{~mm}$ at $5000 \mathrm{~m}$ a.s.l., which rapidly decreases to $<20 \mathrm{~mm}$ per year at $2300 \mathrm{~m}$ a.s.I. at the lee side (Atacama) of Atlantic moisture supply (Houston and Hartley, 2003). The zone below $2300 \mathrm{~m}$ a.s.l. is hyperarid (Houston, 2006b). The narrow coastal strip below ca. $800 \mathrm{~m}$ a.s.l. is fed by precipitation from the Pacific as fog (Houston and Hartley, 2003), but the high coastal cliff (800-2000 m) hampers moisture transport further inland (Cereceda et al., 2008; Houston, 2006a; Rutllant et al., 2013). However, along topographic lows (e.g., Río Loa canyon; Fig. 1A), fog can migrate far inland and allow for localized vegetation (e.g., cacti, Tillandsia lomas, and lichens; Pinto et al., 2006; Schulz et al., 2011).

\subsection{Study area}

The studied clay pan 'Huara' (2004'33'S, 6955'02'W; $1220 \mathrm{~m}$ a.s.I.) is an endorheic basin within the Coastal Cordillera situated in the northern part of the hyperarid core of the Atacama Desert (Fig. 1A and C). The clay pan is formed by tectonic drainage displacement through reverse faulting at the margins of the Huara Intrusive Complex (HIC), which interrupted the connection between a paleo meander to the west and uplifted Jurassic calcareous sandstones of the Caleta Ligate Fm. to the east (Figs. 1C and D; Vásquez and Sepúlveda, 2013). The maximum extent of the clay pan area measures 400 by $500 \mathrm{~m}$ in N-S and E-W direction, respectively. The small catchment area of $12 \mathrm{~km}^{2}$ is mainly located in the HIC, a lower Cretaceous intrusive body of granodiorite and monzonite (Vásquez and Sepúlveda, 2013). Today, the clay pan area and its catchment is barren of vascular plants. Since the Huara clay pan is completely disconnected from runoff of the Altiplano, its fluvial sediment supply reflects local rainfall only. Similarities in basin evolution and hydrological settings between this clay pan and the PAG clay pan further south (Ritter et al., 2019) furthermore make the sediments of the Huara clay pan a suitable target to investigate spatial differences in the precipitation history within the Coastal Cordillera of the Atacama.

\section{Material and Methods}

\subsection{Field work}

\subsubsection{Geophysical survey}

An extensive shallow-seismic site-survey was carried out to analyze the thickness and the internal architecture of the sediment infill of the Huara clay pan basin. The survey was conducted along two profiles perpendicular to each other, spanning the entire visible extent of the clay pan and the reverse fault scarp at its western edge (Fig. 1C and D). Data acquisition was performed using vertical-component geophones as receivers and an accelerated weight drop as seismic source. A fixed spread of 192 receivers with $2 \mathrm{~m}$ spacing 
was used for the North-South (N-S) profile, which results in a profile length of approximately $384 \mathrm{~m}$. The source was activated at every receiver in the center of the profile (receiver numbers 49-145) and at every second receiver for the rest of the profile. A total number of 144 source points along the profile was obtained. For the East-West (E-W) profile the receiver and source parameters were similar but the profile length was doubled to approximately $768 \mathrm{~m}$.

\subsubsection{Coring and core correlation}

Three sediment cores were recovered only a few meters apart from the western central part of the Huara clay pan (Fig. 1D) by a percussion drilling system (Eijkelkamp, NL). Core HU-I was drilled down to approx. $4 \mathrm{~m}$ depth (4 segments) using a percussion gouge auger, and was subsampled in $2-\mathrm{cm}$ resolution in the field. Prior to subsampling, oriented samples (20x16x20 mm cubes) for paleomagnetic measurements were taken from finer-grained horizons and stabilized with epoxy glue. Cores HU-II and HU-III, which cover the upper $1.8 \mathrm{~m}$ (2 segments) and $4 \mathrm{~m}$ (5 segments), respectively, were drilled in opaque liners in order to enable optically stimulated luminescence (OSL) dating.

Correlation of the cores (supplementary material Fig. S1) is based on magnetic susceptibility (MS) data (see section 3.2.2). The resulting core composite has a length of $412.41 \mathrm{~cm}$. The included core sections were subsampled in 2-cm slices for further analyzes. Two minor gaps in the record, at 91.4-98.0 and 279.7-283.5 cm depth, are caused by core loss and lacking overlap of the cores, respectively.

\subsection{Analytical work}

\subsubsection{XRF scanning}

Variations in the inorganic geochemistry were analyzed by non-destructive $X$-ray fluorescence (XRF) scanning on discrete samples (filled in a plastic cube of $6.8 \mathrm{~cm}^{3}$ ). Scanning was performed at 1-mm resolution using an ITRAX core scanner (Cox Analytical, Sweden), and the mean value was calculated for each sample and used for interpretation. The elemental count rates recorded by ITRAX can be used as semi-quantitative estimates of relative concentrations of the detected elements (Croudace et al., 2006). Measurements were carried out with a $1.9 \mathrm{kV}$ chromium $(\mathrm{Cr}) \mathrm{X}$-ray source set to a tube voltage of $30 \mathrm{kV}$ and a 55-mA current with an integration time of $20 \mathrm{~s}$ in order to get low detection limits for lighter elements ( $\mathrm{Al}$ to $\mathrm{Ti}$; Wennrich et al., 2014). Spectra evaluation and data processing was performed using the software QSpec 6.5. Due to the use of two different detectors for the measurements of the HU-II and HU-III samples, elemental count rates are expressed as internally normalized total counts or element count ratios. 


\subsubsection{Magnetic susceptibility}

MS was analyzed by whole-core measurements (1-cm resolution) with a Multi-SensorCore Logger (MSCL, GEOTEK Ltd., UK) equipped with an MS2 control unit and a Bartington MS2C Loop sensor (diameter: $6 \mathrm{~cm}$ ), and on discrete samples using a Kappabridge KLY2 (Agico, CZ).

\subsubsection{Sulphur and carbon contents}

An aliquot of $1 \mathrm{~g}$ of each sample was homogenized and ground to $<63 \mu \mathrm{m}$ for geochemical analyzes. Total sulphur (TS) contents were determined with a vario micro cube elemental analyzer (Elementar Corp., Germany) after combustion of $5 \mathrm{mg}$ of ground sediment mixed with $20 \mathrm{mg}$ of tungsten oxide $\left(\mathrm{WO}_{2}\right)$ as a catalyzer. Total inorganic carbon (TIC) was measured with a DIMATOC 100 carbon analyzer (Dimatec Corp., Germany) on $\mathrm{CO}_{2}$ released through the reaction with ortho-phosphoric acid $\left(\mathrm{H}_{3} \mathrm{PO}_{4} ; 40 \%\right)$ at $160{ }^{\circ} \mathrm{C}$.

\subsubsection{Grain-size distribution}

For grain-size analyzes, an aliquot of approximately $1 \mathrm{~g}$ of each sediment subsample was pretreated with a sodium bicarbonate solution $\left(\mathrm{NaHCO}_{3}, 210 \mathrm{~g} / \mathrm{l}, 12 \mathrm{~h}\right.$ at $\left.60^{\circ} \mathrm{C}\right)$ and hydrochloric acid $(\mathrm{HCl}, 10 \%)$ to remove $\mathrm{CaSO}_{4}$. Prior to the measurement with a LS13320 laser diffraction particle analyzer (Beckman Coulter, USA), the aliquots were dispersed on a shaker for $12 \mathrm{~h}$ using sodium pyrophosphate $\left(\mathrm{Na}_{4} \mathrm{P}_{2} \mathrm{O}_{7}, 2.5 \mathrm{~g} / \mathrm{l}\right)$ and 1-min ultrasonic treatment. Each subsample was measured four times, and the average was used for presentation and interpretation. Grain-size data was processed with the software Gradistat (Blott and Pye, 2001) and evaluated after Folk and Ward (1957).

\subsubsection{Bulk mineralogy}

To evaluate the presence of different calcium sulfate phases, four samples representing the major lithologies were selected and subjected to powder X-ray diffraction analyses. Data was acquired on the homogenized and ground samples using a Bruker D8 Advance diffractometer, equipped with a LYNXE XE detector. Measurements were conducted at 40kV and $40 \mathrm{~mA}$ using copper $\mathrm{K}$ alpha radiation. The scanning range was between 5 and $80^{\circ}$ 2theta with $0.02^{\circ}$ steps per second and performed at ambient conditions. The qualitative and semi-quantitative evaluation of the mineral phases was processed using the software DIFFRAC.EVA (Bruker AXS GmbH, Karlsruhe, Germany).

\subsubsection{Diatom analyzes}

Diatom analyzes were carried out on 17 unequally spaced samples, which were selected in order to reflect all lithologies. According to the standard procedure of acid digestion 
(Battarbee et al., 2001), the sediment samples were treated with hydrochloric acid and hydrogen peroxide, and subsequently washed with distilled water. The residues were evaporated onto glass coverslips and mounted onto permanent slides using the high refractive index medium Naphrax. Diatoms were counted along parallel transects at X1000 magnification using a Zeiss Scope.A1 microscope equipped with differential interference contrast optics and a Canon EOS 700D camera. A very low concentration of diatoms in the samples prohibited to count at least 300 valves per sample, which is generally regarded as the minimum number required for routine quantitative analysis (Battarbee et al., 2001). Instead, a maximum of only 150 valves was counted per sample. Taxonomic identification was based on the general literature (Krammer and Lange-Bertalot, 1986-1991) and more regionally specific diatom-flora references (Frenguelli, 1929; Frenguelli, 1936; Rumrich et al., 2000; Servant Vildary, 1978; Servant Vildary and Blanco, 1984). Autoecological information on the identified taxa was drawn from Cumming and Smol (1993), Servant-Vildary and Mello e Sousa (1993), Servant-Vildary and Roux (1990), Sylvestre et al. (2001), Van Dam et al. (1994), and Vos and de Wolf (1993). Since the diatom content was so low, we adopted a semi-quantitative approach following Sancetta (1979), in which percent abundance data were converted (Table S1) to rank values for the construction of the diatom taxa abundance diagram. By contrast, percent abundances were used for representing the sums of the three main ecological groups found (euplanktonic, non-aerophilic benthic, and aerophilic diatoms).

\subsubsection{Paleomagnetic dating}

Paleomagnetic analyzes involved whole-core measurements (1-cm resolution) and measurements on discrete samples (paleomagnetic cubes). The labs, devices and settings are listed in Table S2. The natural remanent magnetization (NRM) was determined before progressive alternating field $(\mathrm{AF})$ demagnetization experiments were performed. Whole-core material was subjected to three equally spaced demagnetization steps up to $30 \mathrm{mT}$. Demagnetization experiments of discrete samples were performed in sixteen demagnetization steps up to $150 \mathrm{mT}$. Demagnetization data was evaluated by the software Remasoft (Chadima and Hrouda, 2006), and a principle component analysis (Kirschvink, 1980) was carried out. In cases, in which the magnetic mineralogy was dominated by high coercive minerals, the characteristic remanent magnetization (ChRM) of discrete samples was calculated by anchoring 3 to 6 inclination values to the origin; in other respects, the calculation included the origin, but was not anchored to it (settings in Remasoft). Identification and characterization of the carrier of the magnetization was conducted on 15 samples from the HU-III core by mineral-magnetic analysis (for more information see supplementary online information). 
For paleomagnetic dating, the inclination values of whole-core measurements after the $30 \mathrm{mT}$ demagnetization step were used to identify geomagnetic field excursions. Full reversals in the inclination values usually correspond to relative paleointensity (RPI) lows (Channell et al., 2002) and can be used as tie points for the chronology. Additional information is provided by the correlation of the RPI values of the HU-III core with the South Atlantic Paleointensity Stack (SAPIS; Stoner et al., 2002), though the sediments do not provide all requirements for estimation of RPI (King et al., 1983). On the one hand, predominance of magnetite in pseudo-single-domain range is widely given (Fig. S2). On the other hand, changes of the grain-size spectra occur and the presence of hematite may yield to inefficient normalization of the RPI record (Channell et al., 2013). The RPI was approximated by normalizing the remanent magnetization measured after the $10 \mathrm{mT}$ AF demagnetization step by the MS. Thereby, changes in concentration of the magnetic minerals are compensated (Tauxe, 1993). The correlation of the RPI record with the SAPIS (Stoner et al., 2002) was carried out by the use of the software AnalySeries 2.0.8 (Paillard et al., 1996). In the course of this, event layers were omitted due to their short-term formation.

\section{$\underline{3.2 .8 O S L \text { dating }}$}

Selected sediment sections of cores HU-II and HU-III were sampled under subdued red light in the Cologne Luminescence Laboratory (CLL) for OSL dating. For burial dose determination, a total of nine samples were taken and pre-treated following standard procedures to extract the 4-11 $\mu \mathrm{m}$ polymineral and/or the $150-200 \mu \mathrm{m}$ potassium feldspar (Table S5) fractions. Aliquots of $9.8 \mathrm{~mm}$ (fine-grain samples) or $1 \mathrm{~mm}$ (coarse-grain samples) diameter were fixed on steel discs and measured on a Risø TL/OSL reader with a ${ }^{90} \mathrm{Sr} /{ }^{90} \mathrm{Y}$ beta source delivering ca. 0.08 Gy per second at the sample position. OSL signals were stimulated by means of infrared LEDs and detected through an interference filter with peak transmission at $410 \mathrm{~nm}$. Equivalent dose measurements were performed using a postinfrared infrared protocol measured at a temperature of $225^{\circ} \mathrm{C}$ (post-IR $\mathrm{R}_{225}$; Buylaert et al., 2012). Because all OSL samples except the sample HU-III1 showed similar individual fading rates (i.e. g-values) of the post-IR $\mathbb{R}_{225}$ signal (see Table S5), a common mean g-value of $1.1 \pm 0.3 \%$ /decade was used for fading correction following the model of Huntley and Lamothe (2001). For sample HU-III1 at $87.1 \mathrm{~cm}$ depth, which has a significantly higher gvalue of $2.6 \% /$ decade, fading-correction was performed using the sample-specific g-value.

The appropriateness of the applied protocol was confirmed by means of dose recovery tests (mean dose recovery ratios of three aliquots per sample between 0.94 and 1.06) and residual dose measurements $(<2.5 \%$ of the natural equivalent dose), both after solar simulator bleaching for $24 \mathrm{~h}$. For each sample, 6 to 9 (fine grain) and 10 to 41 (coarse grain) aliquots passed standard SAR acceptance criteria in terms of recycling ratio (0.9-1.1) and 
recuperation ( $<5 \%$ of the equivalent dose). For samples with equivalent dose distributions showing over-dispersion values $<12 \%$ (fine grain) and $<40 \%$ (coarse grain), the central age model (Galbraith et al., 1999) was used for burial-dose calculation. Only the coarse-grained samples HU-II1 and HU-II4 with $76 \%$ and $61 \%$ over-dispersion showed evidence of partial bleaching and, thus, required the application of the minimum age model (Galbraith et al., 1999). Dose rate and age calculation were performed using the DRAC software (Durcan et al., 2015), with dosimetry based on radionuclide concentrations (uranium, thorium, potassium) in the surrounding sediment derived from high-resolution gamma spectrometry measured at the CLL and the VKTA Rossendorf.

\subsubsection{Radiocarbon dating}

Accelerator Mass Spectrometer (AMS) radiocarbon dating at the Beta Analytics Laboratory (Miami, USA) was performed on the carbonate of 8 untreated bulk sediment samples, which were selected from the HU-III core based on the TIC contents. Radiocarbon ages were subsequently calibrated with the software Calib 7.0 (Stuiver et al., 2017) using the SHCal13 Southern Hemisphere calibration curve (Hogg et al., 2016).

\section{Results \& Discussion}

\subsection{Sediment geometry}

The exceptionally good seismic data quality causes clearly visible first arrivals, in particular for the N-S profile (Fig. 2B), where they can be observed over the entire profile length for most of the shot gathers. Anthropogenic noise was naturally very low; the only major noise effects resulted from strong wind and local earthquakes. Both noise components were effectively suppressed, the former by vertical stacking of the shot gathers from the same source point and the latter by high-pass filtering to attenuate the low-frequency components resulting from earthquakes. The first arrival travel times were picked for each shot gather along both profiles and a p-wave velocity model was obtained from the travel times by least-squares tomographic inversion. The resulting models are shown in Fig. 2. For both models, the ray coverage in the subsurface has been used to blend the inverted models, showing only those parts that have finite ray coverage.

The velocity model along the E-W profile (Fig. 2A) shows basically a three-layer structure of the Huara clay pan. The first shallow layer (blueish colors) has velocities of around 400 $\mathrm{m} / \mathrm{s}$ and thicknesses that range from around 5-10 $\mathrm{m}$ in the central part to almost zero towards the eastern end of the profile. In the western part the thickness of the uppermost layer is more variable; it increases from the central part until $\mathrm{x}=100 \mathrm{~m}$ with average values of around $20 \mathrm{~m}$, but strongly decreases at the western end of the profile. The second layer 
(greenish colors) yields velocities in the range of 800 to $1000 \mathrm{~m} / \mathrm{s}$ and shows a similar trend as the first layer with respect to thickness along the profile. The thickness in the central part of the profile is around $40 \mathrm{~m}$ and decreases strongly towards the eastern end of the profile. However, the outermost parts of the profile have to be interpreted with care due to the strongly reduced ray coverage in those parts, in particular for this layer. The third layer (reddish colors) resembles the basement with velocities between 2300 and $2700 \mathrm{~m} / \mathrm{s}$, which is in the range of semi-consolidated Oligocene-Miocene clastic deposits of the Central Depression (Labbé et al., 2018). The ray coverage allows to resolve this layer sufficiently well with maximum ray penetration depths of around 80-100 m in the central part of the model. Hence, the general structure of the velocity model implies that the clay pan infill has a maximum thickness in the central part and thins out towards the ends of the profile. However, in the western part the infill has a more complex structure and seems to continue beyond the modern boundary of the clay pan. A sudden drop of thickness of the first layer at $\mathrm{x}=120 \mathrm{~m}$ and a slightly westward shifted step in the boundary between the second and third layer could point to an overthrust-related fault in that part of the model.

The velocity model along the N-S profile (Fig. 2B) shows a very similar structure. Here, the maximum ray penetration depth of about $50 \mathrm{~m}$ is significantly lower than in the E-W profile due to shorter total profile length. However, the same general three-layer case can be observed with similar velocities and thicknesses thinning out towards both profile ends. In the northern part the thinning of the second layer is very clear and evident with a sharp interface between the second layer and the basement, while in the southern part this interface has a more complex structure. One can observe a lens of lower velocity incised from the south into the second layer. This feature cannot be fully explained at the current stage of data processing and interpretation. Possible reasons could be the presence of velocity anisotropy or a coarse-grained sediment body intercalated into more fine-grained deposits.

\subsection{Lithological properties}

Splicing of cores HU-I, -II, and -III (Fig. S1) resulted in a $412.41 \mathrm{~cm}$ long core composite (Fig. 3). The clay pan deposits are mainly composed of dry clay to fine sand of reddish-gray color, which are irregularly intercalated by centimeter- to decimeter-thick sediment layers that show distinct normal grading from gravel or coarse sand to silt and clay. Except of these layers, the sediments are rather massive, lacking any visible stratification. Macroscopic organic matter is missing.

The grain-size distribution of the record exhibits strong but concordant variations in the contents of clay, fine silt, and medium silt throughout the sediment sequence (Fig. 3). In contrast, coarse silt has a more uniform distribution with only sporadic peaks. Fine sand and 
medium sand show a highly variable pattern contrary to the fine fraction. Coarse sand has strongly elevated contents in three distinct depth intervals, which only partly overlap with irregularly-distributed peaks in gravel. Due to the stable gypsic surface in the catchment of the clay pan, it is assumed that aeolian sediment supply to the mud pan is much smaller than fluvial supply. Hence, the highly variable grain-size distribution of the record likely reflects repeated changes in the intensity of fluvial sediment input.

The zirconium/rubidium ratio $(\mathrm{Zr} / \mathrm{Rb})$ and the $\mathrm{MS}$ show distinct positive correlations with the coarse fraction $>250 \mu \mathrm{m}$ (medium sand to gravel; Fig. 3). Due to the resistance of $\mathrm{Zr}$ bearing minerals (i.e. zircon) against physical and chemical weathering (Cuven et al., 2010; Francke et al., 2016), $\mathrm{Zr}$ is commonly enriched in coarse-grained sediments, whereas $\mathrm{Rb}$ concentrations are typically elevated in the fine fraction (Fralick and Kronberg, 1997; Taylor, 1965). Consequently, high values in the $\mathrm{Zr} / \mathrm{Rb}$ ratio are associated with larger grain sizes, whereas low values are indicative for a finer fraction (Dypvik and Harris, 2001). High values of magnetic susceptibility are also attributed to enrichments of coarser sediments, in which the abundance of ferromagnetic minerals (e.g., magnetite) is increased compared to the fine fraction.

Relative XRF intensities of iron ( $\mathrm{Fe}$ ) and potassium (K), which are commonly used as clastic proxies (e.g. Cohen, 2003; Kylander et al., 2011), exhibit a consistent down-core trend that correlates to the abundance of the fine fraction, in particular to the fine silt fraction (4$8 \mu \mathrm{m}$; Fig. 3). This indicates that $\mathrm{K}$ and $\mathrm{Fe}$ are preferably accumulated with the finer fractions. The only exception is the interval between 365.8 and $349.6 \mathrm{~cm}$ depth, where the $\mathrm{K}$ and Fe curves diverge, with a clear peak in $\mathrm{K}$. The relative enrichment of $\mathrm{K}$ points to a higher abundance of volcanic ash particles (cf. Leicher et al., 2016). This suggestion is supported by the strontium/calcium ratio $(\mathrm{Sr} / \mathrm{Ca})$, which is relatively stable throughout the sequence with the exception of a clear peak in the respective interval. The peak reflects enrichment of $\mathrm{Sr}$, as frequently observed in tephra horizons (cf. Vogel et al., 2010). High numbers of ash particles are confirmed by smear-slide analyses. They do not occur as a distinct tephra layer but as a mixture of ash particles and sediment, thereby indicating reworking of an ash rather than a primary deposition.

XRF scanning further yield very high calcium ( $\mathrm{Ca}$ ) counts throughout the record (Fig. 3). $\mathrm{Ca}$ can originate from both clastic and evaporitic sources (Cohen, 2003). By normalizing $\mathrm{Ca}$ to titanium ( $\mathrm{Ti}$ ) as a typical clastic proxy (Kylander et al., 2011), changes in the resulting $\mathrm{Ca} / \mathrm{Ti}$ ratio are commonly used to display variations in the evaporitic and non-clastic component of the Ca signal (e.g. Haberzettl et al., 2007). Similar trends of the Ca/Ti ratio and the sulphur (S) counts in the Huara record (Fig. 3; $\mathrm{R}^{2}=0.90$ ) indicate that the majority of $\mathrm{Ca}$ 
occurs in form of calcium sulfate species (in the following referred to as $\mathrm{CaSO}_{4}{ }^{*} \mathrm{xH}_{2} \mathrm{O}$ ). Bulk mineralogical analyses of 4 samples along the core sequence proved the occurrence of gypsum $\left(\mathrm{CaSO}_{4}{ }^{*} 2 \mathrm{H}_{2} \mathrm{O}\right)$ and $\beta$-anhydrite $\left(\mathrm{CaSO}_{4}\right)$ in variable proportions (Table S6 and Fig. S5). Calcium sulfate in the sediment sequence can be traced back to authigenic precipitation and/or detrital inwash from gypsic crusts or the underlain powdery to weakly cemented surface layer ('chusca') (Ericksen, 1981), which are ubiquitous in the catchment of the clay pan. At least partial detrital supply is confirmed by the finding of detrital calcium sulfate grains in scanning electron microscopy (SEM) images of bulk material of selected samples (Fig. 4). Recent investigations of the surface crust compositions in the Atacama indicate a dominance of anhydrite in the dryer northern part, i.e. in the surrounding of the Huara clay pan, whereas gypsum is more abundant in the southern part that experiences slightly higher precipitation (Voigt et al., 2019). The differences in the spatial distribution are attributed to higher chloride and nitrate concentrations in the only fog-moistened surface layer of the northern Atacama that promotes the formation of $\beta$-anhydrite over gypsum even at low temperatures (Charola et al., 2007). Thus, the presence of $\beta$-anhydrite is rather indicative of dryer and gypsum of moister conditions.

As indicated by TIC contents of up to 1 wt\% (Fig. 3), Ca in the sediment sequence can also occur as $\mathrm{CaCO}_{3}$. Carbonate in soils of the Atacama Desert is often associated with the vegetation-induced formation of rhizoconcretions during wetter periods (Jordan et al., 2014). Nevertheless, SEM images of bulk material of selected samples with elevated TIC show allochthonous detrital carbonate grains (Fig. 4), which most likely originate from Jurassic calcareous sandstones in the western part of the catchment area (Fig. 1; Vásquez and Sepúlveda, 2013).

\subsection{Sediment types}

Based on the sedimentological and geochemical information available, the sediments of the Huara clay pan are subdivided into three major sediment types that reflect different depositional processes.

The sediment type FS (fine-grained sediment) predominantly consists of a mixture of fine to coarse silt with a low $\mathrm{Zr} / \mathrm{Rb}$ ratio and low MS values (Fig. 3). This composition suggests a predominance of low-energy transport processes during only sporadic precipitation events. Limited precipitation is also indicated by high $\mathrm{K}$ and Fe concentrations, reflecting mainly clastic sediment supply of fine-grained weathering product from granodiorites and monzonites of the HIC. Low S, Ca/Ti and TIC values are indicative for a low contribution of calcium sulfate and calcite to the sedimentation. XRD measurements yield the majority of calcium sulfates in sediment type FS to be $\beta$-anhydrite (Table S6). This combination can best 
be explained by a restriction of the fluvial supply to channel systems, where no or only a few millimeters of gypsic crust is present. Hence, the deposition of FS probably represents particularly dry conditions.

The sediment type CS (coarse-grained sediment) shows much higher concentrations of the coarse fraction, in particular of fine sand, and experience higher $\mathrm{Zr} / \mathrm{Rb}$ and MS values (Fig. 3). This composition points to higher fluvial transport energies. Elevated TIC, S and $\mathrm{Ca} / \mathrm{Ti}$ values reflect higher supply of calcium carbonate and sulfate. According to low $\mathrm{K}$ and Fe counts, this supply has significantly diluted the clastic-dominated backgroundsedimentation of FS. The co-occurrence of gypsum and anhydrite in CS deposits (Table S6) contradicts a direct precipitation from the same brine waters; instead, higher water availability may have led to rehydration and incomplete phase-transformation of slope-derived primary anhydrite. The simultaneous presence of carbonate clasts in the CS sediments (Fig. 4A) points to an enhanced inwash of local limestone clasts. The transport energy and sediment sources of CS strongly suggest that the fluvial input to a significant extent was not confined to the channel systems but involved the hills and plains in the catchment. There, rain events may have destabilized the cm-thick gypsic crust, which was eroded and transported as allochthonous clasts into the clay pan. Due to the destruction of the gypsic cover, weathered calcareous sandstones in the western catchment (Fig. 1C) may have become exposed and transported into the pan. Hence, there is strong evidence that CS represents moister conditions in the catchment area, resulting in a higher intensity (frequency and/or amplitude) of precipitation events.

The sediment type GS (graded sediment) is characterized by normal grading from gravel or coarse sand at the base to silt and clay at the top (Fig. 3). The fining-upward is also illustrated by upward decreases in the $\mathrm{Zr} / \mathrm{Rb}$ and MS values. The individual GS layers occasionally exhibit an erosional base. All these characteristics point towards particularly high-energetic discharge during sporadic heavy precipitation events that caused debris and/or sheet flows. Consequently, these sediments can be recognized as event layers, which are up to $36 \mathrm{~cm}$ thick but may be formed in just a few hours or days. The geochemical composition of the GS layers displays similarities to CS, with low $\mathrm{K}$ and $\mathrm{Fe}$ and simultaneous high $\mathrm{S}$ and $\mathrm{Ca} / \mathrm{Ti}$ values, suggesting dilution of the clastic signal due to high sulfate supply. In contrast to CS, the GS layers exhibit only moderate values in TIC. This probably reflects a higher contribution of granodiorite- and monzonite-derived erosional products from the HIC in the more distant eastern catchment (Fig. 1C). 


\subsection{Diatom assemblage}

The low diatom content in all samples was accompanied by a high degree of fragmentation and/or corrosion of the valves. Although 72 taxa were found, the poor preservation of the skeletons allowed only 30 taxa to be recognized to the species level. Semi-quantitative abundance data of the most common taxa are represented in Fig. S6A and the percent abundance data of the three main functional groups are shown in Fig. 3. All samples were largely dominated by aerophilic diatoms, especially the oligosaline Pinnularia borealis Ehrenberg (Fig. S6B), Hantzschia amphioxys (Ehrenberg) Grunow and Luticola mutica (Kützing) Mann. The also aerophilic but meso to polysaline species Denticula elegans Kützing also reaches moderate ranked-abundances. Non-aerophilic benthic diatoms constitute always a minor component of the assemblages, being represented mainly by the oligosaline Cocconeis placentula Ehrenberg, Epithemia adnata (Kützing) Brébisson and by Rhopalodia spp. Some levels indicate also rare to only few euplanktonic diatoms, which belong to Aulacoseira spp. (Fig. S6B) and Cyclotella spp.

In general, this assemblage is compatible with the episodic presence of mostly shallow, ephemeral water bodies in the Huara clay pan. However, the occurrence of euplanktonic diatoms in all three lithofacies indicate that the diatoms may react to every single rain event. Hence, the reconstruction of the precipitation intensity using diatom assemblages is difficult, at least with the amount of samples investigated in and the timespan represented by the Huara record at hand.

\subsection{Chronology}

The chronology for the Huara sediment sequence was established by applying a multimethod approach that is based on OSL, ${ }^{14} \mathrm{C}$ and paleomagnetic dating (Fig. 5, Tables S5 and S7). The OSL ages are in stratigraphic order, ranging from $9.5 \pm 2.0 \mathrm{ka}$ at $19 \mathrm{~cm}$ depth to $65.7 \pm 7.6 \mathrm{ka}$ at $411 \mathrm{~cm}$ at the base of the core (Fig. $5 \mathrm{C}$ ). A much larger spread is visible in eight ${ }^{14} \mathrm{C}$ radiocarbon ages of bulk carbonate available, which range between $7.6 \pm 0.1(1 \mathrm{~cm}$ depth) and $40.6 \pm 0.6 \mathrm{cal}$ kyr $(239 \mathrm{~cm})$ BP. These ages increase with depth only in the upper four samples but are not in stratigraphic order below. This, together with large differences between the $\mathrm{OSL}$ and ${ }^{14} \mathrm{C}$ ages of sediment samples from similar depths, excludes to construct an age-depth model on the basis of these ages alone.

Additional age control comes from the paleomagnetic analyzes, which reveal a continuous section of reversed inclination values between 390.0 and $373.8 \mathrm{~cm}$ depth (Fig. 5A). This section interrupts negative inclination values of the remaining core and correlates with a minimum in the RPI proxy of the Huara record (Fig. 5B). Considering the spread in the OSL and ${ }^{14} \mathrm{C}$ ages (Fig. $5 \mathrm{C}$ ), three geomagnetic events could plausibly be assigned to this 
geomagnetic excursion: (i) The Mono Lake event (33 $\pm 1 \mathrm{ka})$ that is well established in the Northern Hemisphere (Lund et al., 2006 and references therein). (ii) The Laschamp event (41 $\pm 1 \mathrm{ka}$ ) that is excellently documented in the Northern Hemisphere (Lund et al., 2006 and references therein) as well as in the Southern Hemisphere (e.g. Channell et al., 2002; Collins et al., 2012; Stoner et al., 2002) and (iii) The Norwegian-Greenland Sea event that is as yet only reported from sediments of the North Atlantic (ca. $70 \pm 5 \mathrm{ka}$; Bleil and Gard, 1989; Nowaczyk and Baumann, 1992; Nowaczyk and Frederichs, 1999).

From the spread of the OSL and ${ }^{14} \mathrm{C}$ ages, in particular the OSL age of $65.7 \pm 7.6$ ka close to the core base, it is most likely that the excursion detected in the lower part of the Huara record corresponds with the Norwegian-Greenland Sea event. The absence of inclination anomalies for the younger excursions in the Huara sediments above may result from incomplete recording, partial overprint during complex remanence acquisition processes, or regional distortion of the geomagnetic field (Nowaczyk and Frederichs, 1999). Alternatively, it could simply be due to the discontinuous deposition in the clay pan or incomplete core recovery (Fig. 3) taking the short duration of the events (e.g., the Laschamp event lasted only 440 years; Nowaczyk et al., 2012).

Assuming the excursion represents the Norwegian-Greenland Sea event, acting as an anchor point, the age-depth model was further refined by wiggle matching of the HU-III RPI proxy curve to the SAPIS dataset (Stoner et al., 2002; Fig. 5B). For that purpose, the time for the formation of the GS event layers was set to zero. Correlation of the remaining minima and maxima (Fig. 5B) results in several tie points that provide a reasonable age-depth model (Fig. 5C).

The age-depth model is supported by several OSL ages, which plot within the $1 \sigma$ uncertainty on the wiggle-matched curve (Fig. $5 \mathrm{C}$ ). Other four ages seem to overestimate the age model, possibly as a result of incomplete bleaching of the sediment. These samples all originate from sediment type FS, and thus are thought to have experienced only short channel transport during sporadic precipitation events, making an incomplete bleaching likely. Furthermore, the respective ages are based on the polymineral fine-grain fraction. This fraction is prone to incomplete bleaching due to averaging effects on aliquots containing approximately 1 million grains. This has been proven by parallel dating of coarse-grained feldspar for eight samples (Fig. 5C light blue rectangles), which yielded significantly younger ages (see Table S5). The possibility to discriminate completely and partially bleached grains makes ages based on the coarse-grain fraction more reliable.

Of the eight ${ }^{14} \mathrm{C}$ ages only the youngest one $(7.6 \pm 0.1$ in $1 \mathrm{~cm}$ depth) lies on the agedepth curve. Three ages are up to $14 \mathrm{ka}$ too old. A possible explanation for this deviation is 
the contribution of old detrital carbonate from the Jurassic limestones in the catchment (Placzek et al., 2013). On the other hand, four ${ }^{14} \mathrm{C}$ ages are up to $37 \mathrm{ka}$ too young. These ages point to contamination with younger carbonates, possibly provided by carbonaceous rhizoliths, rhizoconcretions of plants (Jordan et al., 2014; Sun et al., 2019), or infiltration of younger carbonate during rain events. $\delta^{13} \mathrm{C}$ and $\delta^{18} \mathrm{O}$ values of the ${ }^{14} \mathrm{C}$-dated carbonates are in line with isotope values of soil carbonates from other sites in the Atacama Desert (Quade et al., 2007), but $\delta^{13} \mathrm{C}$ are much heavier than carbonate $\delta^{13} \mathrm{C}$ from chusca layer (Melchiorre et al., 2018). Furthermore, we cannot exclude contamination by backfall material during the coring process.

Despite the uncertainties in particular in the OSL and ${ }^{14} \mathrm{C}$ ages, the combination of the applied dating techniques has provided a reliable age-depth model for the Huara sediment record. According to this chronology, the sediment sequence dates back to MIS 4 and covers the period from ca. $68 \mathrm{ka} \mathrm{BP}$ until the early Holocene. At the top of the sediment succession a hiatus is indicated, lasting from the mid-Holocene (7.84 ka BP) to the present, which may be due to strongly reduced sediment influx into the clay pan or erosional processes.

\section{Interpretation}

The sedimentological and geochemical properties of the investigated Huara sediment record indicate that changes in sedimentation are predominantly controlled by changes in precipitation intensity and frequency in the clay pan and its fluvial catchment. This makes the Huara record a sensitive archive for the local and regional precipitation history of the past $68 \mathrm{kyr}$ in the northern part of the hyperarid core of the Atacama Desert. In the following we discuss on the basis of two paleo precipitation proxies ( $\mathrm{TIC}$ and $\mathrm{Zr} / \mathrm{Rb}$ ) the precipitation history at the Huara clay pan subdivided into time windows defined by the MIS stratigraphy (Lisiecki and Raymo, 2005). A comparison with available regional and over-regional records from the Atacama Desert and the adjacent Altiplano, as well as marine records offshore the Atacama coast, sheds new light on the temporal and spatial variance of wet periods in the desert, its forcing mechanisms and potential teleconnections.

\subsection{MIS 1 (14-0 ka)}

The youngest sediments preserved in the Huara record date back to around $8 \mathrm{ka}$, thus documenting a significant hiatus at the top of the record (Figs. 5 and 6). Due to absent indications for deflation or fluvial erosion, the lack of mid to late Holocene deposits presumably reflects extremely low fluvial activity in the catchment in consequence of very dry conditions. Similar to observations of recent rain events in the southern Atacama and the results of artificial irrigation experiments, surface runoff during rare precipitation events and subsequent sediment transport into the clay pan was likely buffered by significant infiltration 
into loose sub-surface substrate (Jordan et al., 2015; May et al., 2019). A similar hiatus of several thousand years at the top of the PAG clay pan record at ca. $21.5^{\circ} \mathrm{S}$ (Fig. 1 ; Ritter et al., 2019) suggests that larger parts of the Coastal Cordillera of the Atacama experience a pronounced dry phase since the mid Holocene.

Synchronous arid conditions are also reconstructed from records of the Salar de Uyuni (205; Baker et al., 2001; Fritz et al., 2004), the Salar de Coipasa (19.4 S; Nunnery et al., 2018) as well as rodent middens between $25^{\circ}$ and $22^{\circ} S$ (Betancourt et al., 2000; De Porras et al., 2017). On the other hand, a mid to late Holocene wet phase is documented in the Salar de Atacama $\left(23^{\circ} \mathrm{S}\right.$; Bobst et al., 2001) as well as the Sierra de Varas (24.8 S; Sáez et al., 2016), the Laguna Miscanti (22,8 $8^{\circ}$; Grosjean et al., 2003), and paleowetlands between $22^{\circ}$ and $24^{\circ} \mathrm{S}$ (Rech et al., 2002). Furthermore, coastal alluvial fans (CAF; Walk et al., 2019) along the coastal cliff of the Atacama (between $21^{\circ}$ and $24.5^{\circ} \mathrm{S}$ ) show higher activity during the mid and late Holocene (Bartz et al., 2019) that is thought to be linked to El Niño conditions off the coast (Vargas et al., 2006). These discrepancies point to a short-term variability and/or spatial heterogeneity in the precipitation patterns over the Atacama region.

During the late Pleistocene to mid Holocene (ca. 14-8 ka), relatively low $\mathrm{TIC}$ and $\mathrm{Zr} / \mathrm{Rb}$ values in the Huara record in combination with a predominance of sediment type FS point to overall dry climate conditions (Fig. 6A to C). Concordant stable aridity throughout MIS 1 is also indicated for the PAG record (Ritter et al., 2019; Fig. 6D) and the Salar Grande area at $21^{\circ} \mathrm{S}$ (Fig. 6E), where hillslope activity was strongly reduced (Medialdea et al., 2019). A higher aeolian sediment content in the terrigenous fractions of marine sediments offshore northern Chile at $27.5^{\circ} \mathrm{S}$ (Stuut and Lamy, 2004) and $30^{\circ} \mathrm{S}$ (Bernhardt et al., 2017; GeoB7139; Fig. 6H) suggest prevailing arid conditions during the Late Pleistocene and Early Holocene even beyond the hyperarid core. The occurrence of a graded GS layer at around 9.5-10 ka, however, implies that the arid episode in the Huara record was seldomly interrupted by high-precipitation events that caused severe flash floods. Recent intense flooding events in 2015 and 2017 at the Salado River (Bozkurt et al., 2016; Wilcox et al., 2016) and in the Yungay area (Azua-Bustos et al., 2018), respectively, could be present-day analogues for such flood events. Nevertheless, missing links of the flood event documented in Huara to other records (Fig. 6) suggest an only local extent of the precipitation event.

In contrast to the sites from the Coastal Cordillera, further to the east elevated water levels in the Salar de Atacama (Bobst et al., 2001), wetlands in various parts of the Atacama Desert (Quade et al., 2008; Rech et al., 2002) and formation of rodent middens (Betancourt et al., 2000; De Porras et al., 2017) highlight a distinct wetter phase between ca. 14 and 10 ka, which is known as the 'Central Andean Pluvial Event II' (CAPE II; Quade et al., 2008). 
In the Altiplano, this wetter period corresponds to the 'Coipasa' paleolake phase, which is known, for instance, from lakes Titicaca (Baker et al., 2001) and Chungará (Bao et al., 2015), the Salar de Uyuni (Baker et al., 2001; Fritz et al., 2004), and the Salar de Coipasa (Nunnery et al., 2018). The divergent precipitation patterns during this interval, with dryer conditions in the western part of the Atacama simultaneous with wetter conditions in the eastern part and the Altiplano, points to a moisture source from the east that could not reach the Coastal Cordillera.

\subsection{MIS $2(29-14 \mathrm{ka})$}

During MIS 2, the Huara record experienced a distinct shift towards coarser grain sizes and higher TIC values at ca. $16.4 \mathrm{ka}$, with only minor fluctuations until ca. $28.5 \mathrm{ka}$ (Fig. 6B and $\mathrm{C}$ ). The predominance of relative uniform CS sediments during this period (Fig. 6A) points to more regular fluvial sediment input into the clay pan rather than a series of flood-like events. This indicates a phase $(16.4-28.5 \mathrm{ka})$ of prolonged moister conditions at the northern edge of the hyperarid core compared to the modern climate of the Atacama Desert, which is interrupted by a short-term swing back to more arid conditions between ca. 18.0 and $18.8 \mathrm{ka}$. The moister periods in the Huara record coincide very well with the grain-size based humidity index derived from marine cores GeoB3375 and GeoB7139 offshore northern Chile (Fig. 6H) that show a pronounced plateau of higher values interpreted as lower aeolian contribution of Atacama dust (Stuut and Lamy, 2004). Somewhat larger differences, in contrast, occur to the timing of a wetter period in the records from the Salars de Uyuni and Coipasa during the MIS 2 (Fig. 6C, I, J). The temporal offset could be due to uncertainties in the chronologies of the individual records and/or variable proxy-response to climatic forcing. Fritz et al. (2004) link these intervals in the Uyuni record to the well documented 'Coipasa' (10.6-13 ka) and 'Tauca' (15-26 ka) lake phases. These ages, however, predate paleo shoreline ages of the 'Coipasa' and 'Tauca' paleolake in the Bolivian Altiplano (11-13 ka and 14.1-18.1 ka; Placzek et al., 2006; Placzek et al., 2013). These partly contradictory chronologies of the Altiplano paleolake phases hamper a straightforward correlation of the Huara wet phase to one of these paleolakes.

In the Atacama Desert, a widely coincident peak wet phase (16.5-26.7 ka) is also reported from the Salar de Atacama, reflected by perennial lake conditions (Bobst et al., 2001). Furthermore, the existence of rodent middens (Betancourt et al., 2000; De Porras et al., 2017; Díaz et al., 2012; Maldonado et al., 2005), paleolakes, and wetlands in the Pampa del Tamarugal (PDT; 19.5-20.5 S; Pfeiffer et al., 2018) experienced an apparent cluster during this 'CAPE I' phase (14.2-17.5 ka; Quade et al., 2008) and several short-term 'pre-CAPE events around 25-27 ka and 19 ka. Enhanced CAF activity between 20 and 25 ${ }^{\circ}$ (Fig. 6F) also points to wetter climates around 19 to $33 \mathrm{ka}$ (Bartz et al., 2019). Surprisingly, the PAG 
precipitation record from the central part of the hyperarid core yielded only one exceptional flooding event visible in an MS peak at approx. $17 \mathrm{ka}$ (Ritter et al., 2019), which may correspond to the younger wet phase in Huara. During the older wet phase, in contrast, the PAG record indicates rather dry conditions. This is synchronous with strongly reduced hillslope activity at the Salar Grande during MIS 2 (Medialdea et al., 2019), thereby indicating a pronounced spatial heterogeneity in the precipitation patterns across the hyperarid core during parts of MIS 2.

\subsection{MIS $3(57-29 \mathrm{ka})$}

In contrast to MIS 2, the interval in the Huara sequence that belongs to MIS 3 (57-29 ka) is characterized by more variable climatic conditions. Strong variations in both the $\mathrm{Zr} / \mathrm{Rb}$ ratio and the TIC concentration (Fig. 6B and C) imply short-term fluctuations from arid to more moist conditions. The late MIS 3 is marked by a pronounced low in the Huara precipitation proxies from ca. 28.5 to $33.6 \mathrm{ka}$ that can be traced back to a longer-lasting period of predominant aridity in the study area. A similar, although chronologically shifted trend to lower lake levels is also documented in the records from the Salar de Uyuni (Fritz et al., 2004) and the Salar de Coipasa (Nunnery et al., 2018) at ca. 26-28 ka (Fig. 6l and J). The apparent \pm 4 kyrs age offset between the Huara and Uyuni records may be explained by agemodel uncertainties. The dry phase in Huara is furthermore concordant with a lower humidity index in marine core GeoB3375 (Stuut and Lamy, 2004), and an obvious lack of wetland and rodent midden records during this interval (Fig. $6 \mathrm{~L}$ and $\mathrm{M}$ ), thus indicating a regional rather than a local climate signal. In contrast, the more proximal records from the PAG site and the Salar Grande hillslope profile (Medialdea et al., 2019; Ritter et al., 2019) document enhanced, although likely episodic precipitation during this period. As both sites are situated geographically close by, the higher precipitation may have been due to a very local weather phenomenon.

During most of the MIS 3, however, the Huara record experience several lower-amplitude pluvial phases between ca. 33.6-36.8 ka, 39.1-40.9 ka, 41.6-42.0 ka, 45.1-49.9 ka, 50.6$52.8 \mathrm{ka}$, ca. $57 \mathrm{ka}$, and $58.3 \mathrm{ka}$, interrupted by short-term dry spells (Fig. 6). This complex of these pluvial phases might correspond to the L3 and L4 lacustrine phases (ca. 36-46 ka; Baker and Fritz, 2015; Baker et al., 2001) in the Uyuni record (Fig. 6l), keeping the discrepancies in downcore chronologies in mind. A similar bimodal wetter period during the older part of MIS 3 is documented in marine sediments offshore the Atacama (Stuut and Lamy, 2004) and Salar de Coipasa (Nunnery et al., 2018), whereas for the Salar de Atacama, persistent shallow ephemeral lake conditions have been reconstructed (Bobst et al., 2001). Enhanced moisture is also evidenced by 'pre-CAPE sediments of the Quebrada Chipana at ca. $36.1 \mathrm{ka}$ (PDT around $20.5^{\circ} \mathrm{S}$; Fig. $6 \mathrm{~L}$ ), by laminated carbonates in the Aguas 
Blancas basin at ca. $35.9 \mathrm{ka}$, and by dated wetlands from the Salar Aguas Blancas at ca. $47 \mathrm{ka}$ (ca. 24 S; Pfeiffer et al., 2018). Rodent middens findings at ca. $37 \mathrm{ka}$ (Quebrada La Higuera; $18^{\circ}$ S; Mujica et al., 2015) and ca. 37.3, 40.5 and 45.8 ka (Maldonado et al., 2005) also suggest increased precipitation during these periods (Fig. 6M).

Although relatively synchronous, the rather variable conditions documented in the Huara precipitation record contradict a long-lasting constant moisture supply to the Coastal Cordillera. Rather, they indicate periodic fluctuations between moister and more arid conditions. This is confirmed by precipitation changes reconstructed for the PAG clay pan, which exhibit high-frequent but low-amplitude variations during MIS 3 (Ritter et al., 2019) that partly match the Huara wet phases at ca. 33.6-57 ka (Fig. 6C and D). CAFs experienced a distinct activity maximum between ca. 40 and $45 \mathrm{ka}$ (Bartz et al., 2019). Hillslope activity at the Salar Grande, in contrast, remained generally low during this interval with only one remarkable activity phase between ca. 48 and 58 ka (Medialdea et al., 2019). Nevertheless, the lower temporal resolution and larger age-uncertainties of the Salar profile and the CAF's hamper the comparability of the records and an assignment to certain events.

\subsection{MIS 4 (71-57 ka)}

At the termination from MIS 3 to 4, a sharp drop of the TIC values in the Huara record and a change from lithofacies CS to a predominance of FS suggest a distinct shift from a moister MIS 3 to extremely arid conditions at the end of MIS 4 (Fig. 6A and C). These hyperarid conditions persisted for ca. 3 kyrs during the final phase of MIS 4 (ca. 58.3-61 ka). A similar pattern is also expressed by the deposition of a subaerial halite in the Salar des Atacama record between ca. 53.4 and $60.7 \mathrm{ka}$ (Bobst et al., 2001). In contrast, lacustrine deposits of lake phase L5 in the Salar de Uyuni record rather point to wetter conditions (Baker and Fritz, 2015; Fornari et al., 2001). However, taking into account a systematic offset of the Huara and Uyuni chronologies, we tentatively link this dry spell at Huara with a pronounced shallow-lake phase in between the L4- and L5-paleolake phases, which was dated to ca. 48-55 ka (Fig. $6 \mathrm{I})$. Alternatively, a correlation of the dry phase in Huara to the shallow lake and salt pan episode between the L5- and the previous L6 lake phases (ca. 65-70 ka; Fritz et al. 2004) cannot be excluded. Similarly, the hillslope profile at the Salar Grande indicate a period of low activity between ca. 57-66 ka (Medialdea et al., 2019), and also the marine record offshore the Atacama point to stable arid conditions (Stuut and Lamy, 2004). In the PAG record, unfortunately, this interval is only poorly recovered (Ritter et al., 2019).

The oldest part of the Huara record (ca. 61-67.8 ka) again documents a shift to moister conditions, however with high amplitude variability (Fig. 6). Following the correlation with the Salar de Uyuni record presented above, this MIS 4 wet phase in Huara might be correlated 
with lacustrine phase L5 or L6 that was dated to ca. 55-60 and 65-70 ka, respectively, when the Uyuni record suggests a persistent salty lake (Baker and Fritz, 2015). Other MIS 4 archives from the Atacama Desert are sparse. Nevertheless, the majority of the available records, like the Salar de Atacama core (Bobst et al., 2001), the marine core GeoB3375 (Stuut and Lamy, 2004) and the Salar Grande hillslope profile (Medialdea et al., 2019), indicate a rather consistent despite partly shifted picture of moister conditions. In contrast, both the PAG clay pan record (Fig. 6D) and the CAFs (Fig. 6F) rather point to predominating aridity. But still, the tentative correlation of wetter trends in the older part of the record has to be treated with caution due to the sparcity of records and large uncertainties within the chronologies.

\subsection{Drivers of precipitation changes}

The complexity of atmospheric circulation systems over western South America and the eastern South Pacific is postulated to have a strong impact on the moisture supply to the Atacama Desert (e.g. Marin and Barrett, 2017; Reyers and Shao, 2019). As the Atacama Desert is subdivided into two precipitation zones, local climates are spatially influenced either by summer or by winter rainfall (Houston, 2006b; see dashed line in Fig. 1). Winter rain mainly originates from southerly and westerly Pacific air masses causing frontal precipitation in coastal areas from extra-tropic cyclone systems (Vuille, 1999). During summer, northeasterly airflows sourced in the Atlantic Ocean transport advective moisture via the Amazon basin to the Andean mountain range (Garreaud et al., 2003). In the geological past the North-South distribution of summer precipitation is postulated to be mainly governed by the strength of N-NE and S climatic modes (Sáez et al., 2016).

One of the striking features of the Huara precipitation record is the resemblance of the pattern to lake and salar records from the Altiplano, especially from Salar de Uyuni (Fig. 6). As the Huara site in the Coastal Cordillera is hydrologically completely decoupled from Andean and Altiplano runoff, this resemblance strongly suggests a common moisture source of both the Northern Coastal Cordillera and the Altiplano for most of the past ca. $68 \mathrm{ka}$ represented by the Huara record. This partly contradicts previous studies, which postulated the Huara area to be predominately influenced by winter rain, whereas the Altiplano sites are located in the summer rain area (Houston, 2006b). A recent composite study by Marin and Barrett (2017) for present day conditions indicates that above-normal atmospheric moisture over the Chajnator plateau in the Precordillera is associated to a mid-tropospheric trough over the Southeast Pacific during winter, spring, and autumn, and to a southward displacement of the Bolivian High during summer. Both circulation patterns lead to increased precipitable water along a Northwest-Southeast oriented strip ranging from the subtropical Southeast Pacific to continental areas south of $30^{\circ} \mathrm{S}$. As both, the Huara site and the 
Altiplano are located in this region, one might speculate that past precipitation anomalies at these both sites are triggered contemporaneous by past changes in the atmospheric circulation. Both, modelling and proxy studies suggest that the atmospheric circulation in the study area indeed underwent significant changes in the past (e.g. Maldonado et al., 2005; Reyers and Shao, 2019). For example, stronger tropical easterlies generated more summer precipitation in the southern Atacama Desert during the late glacial (11-14 cal. yrs. BP), while in earlier episodes expanded southern westerlies resulted in wetter winters (Maldonado et al., 2005). Past multi-millennial changes in the frequency of occurrence of this circulation pattern might therefore cause longer intervals of elevated precipitation in both the Huara clay pan and the Altiplano.

A rather rare synoptic feature for the study area are cut-off lows, which usually form from deepening troughs (e.g., Marin and Barrett, 2017) and transport moisture from the Eastern Tropical Pacific to the coast of the Atacama Desert (Pizarro and Montecinos, 2000; Reyers and Shao, 2019). Such a cut-off low accompanied with anomalous warm sea-surface temperature (SST) over the Eastern Tropical Pacific is thought to be the cause for the extreme precipitation event in March 2015 (Bozkurt et al., 2016). Consequently, the occurrence of strong cut-off lows might have caused the short-term flood events in the Huara clay record (event-driven weather phenomena).

The precipitable water signals for the different circulation patterns identified by Marin and Barrett (2017) reveal strong north-south gradients along the Atacama Desert. Taking into account these gradients, past changes in the circulation might thus have contributed to the heterogeneity in the timing and intensity of the precipitation signals detected in the Huara record and in the Salar Grande (Medialdea et al., 2019) and PAG records (Ritter et al., 2019) located further south. The CAFs, instead, cannot contribute to the reconstruction of the weather phenomena, since they stretch over a wide latitudinal range from $21^{\circ}$ to $24.5^{\circ} \mathrm{S}$ (Bartz et al., 2019) and thus amalgate extreme rain events over a north-south transect.

The humidity changes inferred from grain-size data of marine sites GeoB3375 and GeoB7139 at $27^{\circ} \mathrm{S}$ and $30^{\circ} \mathrm{S}$, respectively (Bernhardt et al., 2017; Stuut and Lamy, 2004), do not correspond with the moisture reconstruction from the PAG clay pan and Salar Grande in the central Atacama Desert, but surprisingly match the precipitation pattern during the past ca. $68 \mathrm{ka}$ of the Huara site further north. As the marine sites are located offshore the southernmost limits of the Atacama Desert, these records might be influenced by an independent climate regime. Indication to that may come, first, from the fact that humidity variations were reconstructed from the marine cores on the basis of grain-size changes that reflect the ratio of aeolian vs. fluvial input (Stuut and Lamy, 2004). Second, synoptic analysis 
of a recent dust event in 2016, which was sourced in the northern Atacama between 18 and $20^{\circ} \mathrm{S}$ (Reyers et al., 2019), yielded a massive southward dust transport along the Atacama coast to higher latitudes. Hence, the aeolian component in the marine cores presumably does not display solely a local source. The cores rather trap dust from larger parts of the Atacama and even more likely the Bolivian Altiplano, which is regarded as a major dust source on the west coast of South America (Prospero et al., 2002; Saukel et al., 2011). As dust availability in the Bolivian Altiplano, in turn, depends on moisture in this area, this can explain the concordant humidity signals of the marine cores in the southern Atacama and the continental sites in the northern Atacama and Altiplano.

Furthermore, previous studies have indicated moist periods in the Atacama Desert to be linked to higher SST of the Pacific offshore Chile and Peru (Ritter et al., 2019). Precipitation changes in the Huara record also exhibit a strong dependency to SST changes in the SE Pacific offshore the Southern Atacama Desert (GIK 17748: 32.8 S; GeoB3302: $33.2^{\circ} \mathrm{S}$; Kim et al., 2002), but also in the equatorial eastern Pacific at $0.7^{\circ} \mathrm{S}$ (ODP 1239: 0.7 S; RincónMartínez et al., 2010). This dependency, however, is an apparent anti-correlation: periods of higher SST are marked by arid conditions in the northern hyperarid core of the Atacama, whereas higher precipitation occur during phases of diminished SST. An explanation may come from modelling experiments including present-day and LGM climate settings by Reyers and Shao (2019), who conclude that under LGM conditions, when the SST is expected to be lower, non-uniform global temperature changes in the troposphere result in alterations of the zonal winds and thus favors the formation of cut-off lows off coast of the Atacama Desert. Consequently, the frequency of cut-off lows during the LGM was distinctly (up to 50\%) higher than present, which may have caused concurrent wetter periods around the Huara clay pan.

On geological timescales, the occurrence of anomalous precipitation in the northern Atacama might also be paced by orbital parameters. In fact, moisture changes in the Huara record show an overall correspondence to the local summer (Oct-Mar) insolation at $20^{\circ} \mathrm{S}$ (Berger, 1978; Fig. 6), with reconstructed wet and arid periods correlating with insolation maxima and minima, respectively. A similar strong insolation forcing of wet periods has been observed and was mainly attributed to precession-paced variations in the intensity of the SASM for multiple sites in the Andes of Ecuador, Peru, and Bolivia (Baker and Fritz, 2015). Findings from rodent middens from the Calama-Salar de Atacama basins of the Central Atacama, in contrast, indicated a contrary relation, with maximum precipitation during summer insolation minima (Betancourt et al., 2000; Latorre et al., 2002). These anti-phasing is traced back to a dominating extraregional and interhemispheric forcing of the SASM intensity, including changes in the Walker Circulation and El Niño/Southern Oscillation (ENSO). The Huara record exhibits low concordance of precipitation changes and the 
ENSO-indicative NINO3 index (Clement et al., 1999; Fig. 6N) during MIS 1 and 2, which argues against a significant ENSO forcing, at least on longer timescales. For MIS 3-4, in contrast, moister conditions in Huara are coherent with enhanced El Niño conditions in the NINO3 index. This implies precipitation changes in the northern Atacama Desert to be at least temporarilly superimposed by shifts in the ENSO forcing.

\section{Conclusion}

From a geophysical site survey and the multi-disciplinary investigation of a $4.1 \mathrm{~m}$ long sediment record from the central part of the Huara clay pan, an endorheic basin in the Coastal Cordillera of northern Chile, the following conclusions can be drawn.

(i) The record provides an excellent and (quasi)continuous archive of precipitation changes in the northern part of the hyperarid core of the Atacama Desert since ca. $68 \mathrm{ka} \mathrm{BP}$. Precipitation changes are predominantly reflected by the sedimentological, geochemical and mineralogical characteristics of three distinct sediment types. Age control is provided by the results of ${ }^{14} \mathrm{C}$, OSL and paleomagnetic dating.

(ii) Precipitation changes took place on orbital but also on millennial time scales. Rather moist periods were reconstructed for most of MIS 2 (ca. 16.4-28.5 ka BP), several shorter periods within MIS 3 between ca. 33.6 and $58 \mathrm{ka} \mathrm{BP}$ and most of the period $>61 \mathrm{ka} \mathrm{BP}$ in MIS 4. The driest phase probably occurs since ca. $8 \mathrm{ka} \mathrm{BP}$, when negligible sediment supply probably reflects virtual absence of fluvial activity in the catchment.

(iii) The Huara precipitation record exhibits an overall concordance with lake, salar, and rodent midden records in the Bolivian Altiplano and Pre-Andean depression as well as with marine records offshore the southern Atacama, but a misalignment with records from the Coastal Cordillera further to the south. This suggest a strong precipitation heterogeneity across the Atacama that is caused by pronounced differences in the dominating climate patterns and a shift from predominant summer rain in the north to winter rain in the south. An anti-correlation of the Huara precipitation changes with the SE Pacific SST suggest that precipitation supply is independent on the temperatures of the adjacent ocean; it rather seems to depend on the intensity of cut-off lows and the South American Summer Monsoon.

(iv) Seismic data along two profiles crossing the Huara clay pan indicate a three-layer structure of the basin, with two presumable sediment units underlain by bedrock. The most undisturbed deposits were detected in the basin center, where the maximum sediment thicknesses of ca. $10 \mathrm{~m}$ occur (sediments similar to the Huara record). Extrapolating the mean sedimentation rate determined for the $4.1 \mathrm{~m}$ Huara record to the sediment base 
indicated in the seismic data, the onset sedimentation in the basin can be estimated to ca.166 ka.

\section{Acknowledgement}

This study was funded by the German Research Foundation within the scope of the Collaborative Research Center 1211 - Earth Evolution at the Dry Limit. Special thanks go to the Universidad Católica del Norte for the logistic support during field campaigns. Joel Mohren, Andreas Vogt, Christian Tiede, Jakub Surma, Rebekka Keulertz and Damian Lopez are thanked for their competent help in collecting the sediment cores. We are grateful to the Geophysical Instrument Pool Potsdam and Klaus Bataille, Universidad de Concepción, for providing seismic field equipment and we acknowledge Nicole Mantke, Dorothea Klinghardt, Hanna Cieszynski and various student assistants for their support during the analytical work at the University of Cologne.

\section{Supplementary data}

Supplementary data to this article can be found online at https://doi.org/10.1016/j.gloplacha.2019.103054.

\section{Captions}

Fig. 1. A. Color-shaded digital elevation model (DEM; derived from SRMT-data, produced by ArcGIS 10.5.1) with isohyets and the border between winter- and summer-rain dominated areas after Houston (2006b), showing the locations of reference records from the PAG clay pan, rodent middens ( $<50 \mathrm{ka})$, salars in the Altiplano and Precordillera and coastal alluvial fans (CAF) and hillslopes in the coastal region. B. Overview map of South America with the position of the study area and locations of marine records mentioned in the text. C. DEM of the study area (derived from Pléiades and Sentinel-data, created using ArcGIS 10.5.1) superimposed by geological units, faults (according to Vásquez and Sepúlveda (2013) and the clay pan's catchment area. D. Zoom-in of the clay pan in the DEM with coring location and seismic profiles indicated.

Fig. 2. P-wave velocity model along the East-West profile $(A)$ and the North-South profile (B) crossing the Huara clay pan (for locations see Fig. 1D). The black vertical line marks the crossing point of the profiles, the white circles the layer boundaries and the white bar the coring location.

Fig. 3. Sediment types, diatom assemblage, grain-size distribution, $M S, Z r / R b, F e, K, S$, $\mathrm{Ca} / \mathrm{Ti}, \mathrm{TIC}$ and $\mathrm{Sr} / \mathrm{Ca}$ values of the composite record displayed versus depth. Colored background marks the lithological zones defined. 
Fig. 4. SEM images of bulk material of selected samples with elevated TIC contents. A. Detrital calcium carbonate grain. B. Detrital grain from gypsic crust with calcium sulfate overgrowth.

Fig. 5. Age-depth model. A. Paleomagnetic inclination record of Huara core HU-III. Dashed lines show unreliable inclination directions that were not taken into account. $B$. Wiggle matching of the relative paleointensity (RPI) proxy from core HU-III versus the SAPIS RPI stack of Stoner et al. (2002). The event layers of sediment type GS were omitted because of high sedimentation during short time intervals. The Norwegian-Greenland Sea event was assigned to the RPI minimum at ca. $65 \mathrm{ka} \mathrm{BP}$. C. Age-depth model derived from wiggle matching using the software AnalySeries 2.0.8 (Paillard et al., 1996). OSL and ${ }^{14} \mathrm{C}$ ages were plotted with their $1 \sigma$ and $2 \sigma$ confidence intervals, respectively. D. Sediment types plotted versus age.

Fig. 6. Reconstructed wet phases in the Huara clay pan record versus age compared to selected climate records from continental and marine sites in South America (for locations see Fig. 1A and B). Light blue and light green-colored background underlines the more robust and tentative correlations between the paleoclimate archives, respectively. Intense blue color infill indicates wet phases in the individual paleoclimate records. A. Sediment types as defined in Figs. 3 and 5 (vertically striped signature indicates gaps). B. $\mathrm{Zr} / \mathrm{Rb}$ ratio of the Huara record. C. TIC concentrations of the Huara record overlaid by local mean summer insolation (Oct-Mar) as red line (Berger, 1978). D. Magnetic susceptibility from the PAG clay pan record in the central part of the hyperarid core of the Atacama Desert (Ritter et al., 2019). E. Periods of hillslope activity at the Salar Grande (Medialdea et al., 2019). F. Periods of coastal alluvial fan activity between $20^{\circ}$ and $25^{\circ} \mathrm{S}$ (Bartz et al., 2019). G. SST reconstructions from the East Pacific Ocean offshore Peru (ODP 1239; Rincón-Martínez et al., 2010) and Chile (GIK 17748; GeoB3302; Kim et al., 2002). H. Humidity index of marine cores GeoB3375 (Stuut and Lamy, 2004) and GeoB7139 (Bernhardt et al., 2017) offshore the southern Atacama. I. Natural gamma ray (NGR) of the Salar de Uyuni core (Fritz et al., 2004). J. Ca percentage of a sediment core from Salar de Coipasa (Nunnery et al., 2018). K. Sediment record of the Salar de Atacama with lighter blue colors implying saline lake phases, intense blue colors marking a perennial saline lake phase and dashed pattern indicating saline mudflats (Bobst et al., 2001). L. 'Pre-CAPE (Pfeiffer et al., 2018), and 'CAPEs' (Quade et al., 2008) phases reconstructed from paleowetlands and lacustrine deposits in the Central Atacama. M. Rodent middens occurrence in the Atacama region (Betancourt et al., 2000; De Porras et al., 2017; Díaz et al., 2012; Maldonado et al., 2005; Mujica et al., 2015). N. ENSO intensity as indicated by the 500 -year averaged NINO3 index (Clement et al., 1999). 


\section{References}

Alpers, C.N. and Brimhall, G.H., 1988. Middle Miocene climatic change in the Atacama Desert, northern Chile: Evidence from supergene mineralization at La Escondida. Geological Society of America Bulletin, 100(10), 1640-1656.

Azua-Bustos, A., Fairén, A.G., González-Silva, C., Ascaso, C., Carrizo, D., FernándezMartínez, M. Á., Fernández-Sampedro, M., García-Descalzo, L., García-Villadangos, M., Martin-Redondo, M. P., Sánchez-García, L., Wierzchos, J. and Parro, V., 2018. Unprecedented rains decimate surface microbial communities in the hyperarid core of the Atacama Desert. Scientific Reports, 8(1), 16706.

Baker, P.A. and Fritz, S.C., 2015. Nature and causes of Quaternary climate variation of tropical South America. Quaternary Science Reviews, 124, 31-47.

Baker, P.A., Rigsby, C.A., Seltzer, G.O., Fritz, S.C., Lowenstein, T.K., Bacher, N.P. and Veliz, C., 2001. Tropical climate changes at millennial and orbital timescales on the Bolivian Altiplano. Nature, 409, 698.

Bao, R., Hernández, A., Sáez, A., Giralt, S., Prego, R., Pueyo, J.J., Moreno, A. and ValeroGarcés, B.L., 2015. Climatic and lacustrine morphometric controls of diatom paleoproductivity in a tropical Andean lake. Quaternary Science Reviews, 129, 96110.

Bartz, M., Walk, J., Binnie, S., Brill, D., Stauch, G., Lehmkuhl, F., Hoffmeister, D. and Brückner, $H_{\text {., }}$ this issue. Late Pleistocene alluvial fan evolution along the coastal Atacama Desert (N Chile). Global and Planetary Change.

Battarbee, R., Jones, V.J., Flower, R.J., Cameron, N.G., Bennion, H., Carvalho, L. and Juggins, S., 2001. Diatoms, 155-202. Tracking Environmental Change Using Lake Sediments, 3.

Berger, A., 1978. Long-Term Variations of Daily Insolation and Quaternary Climatic Changes. Journal of the Atmospheric Sciences, 35(12), 2362-2367.

Bernhardt, A., Schwanghart, W., Hebbeln, D., Stuut, J.-B.W. and Strecker, M.R., 2017. Immediate propagation of deglacial environmental change to deep-marine turbidite systems along the Chile convergent margin. Earth and Planetary Science Letters, 473, 190-204.

Betancourt, J., Latorre, C., Rech, J., Quade, J. and Rylander, K., 2000. A 22,000-year record of monsoonal precipitation from northern Chile's Atacama Desert. Science, 289(5484), 1542-1546.

Bleil, U. and Gard, G., 1989. Chronology and correlation of Quaternary magnetostratigraphy and nannofossil biostratigraphy in Norwegian-Greenland Sea sediments. Geologische Rundschau, 78(3), 1173-1187.

Blott, S.J. and Pye, K., 2001. GRADISTAT: a grain size distribution and statistics package for the analysis of unconsolidated sediments. Earth Surface Processes and Landforms, 26(11), 1237-1248.

Bobst, A.L., Lowenstein, T.K., Jordan, T.E., Godfrey, L.V., Ku, T.L., and Luo, S., 2001. A 106ka paleoclimate record from drill core of the Salar de Atacama, northern Chile. Palaeogeography, Palaeoclimatology, Palaeoecology, 173(1), 21-42.

Bozkurt, D., Rondanelli, R., Garreaud, R. and Arriagada, A., 2016. Impact of Warmer Eastern Tropical Pacific SST on the March 2015 Atacama Floods. Monthly Weather Review, 144(11), 4441-4460.

Buylaert, J.P., Jain, M., Murray, A.S., Thomsen, K.J., Thiel, C., and Sohbati, R., 2012. A robust feldspar luminescence dating method for Middle and Late Pleistocene sediments. Boreas, 41(3), 435-451.

Cereceda, P., Larrain, H., Osses, P., Farías, M. and Egaña, I., 2008. The climate of the coast and fog zone in the Tarapacá Region, Atacama Desert, Chile. Atmospheric Research, 87(3), 301-311.

Chadima, M. and Hrouda, F., 2006. Remasoft 3.0 a user-friendly paleomagnetic data browser and analyzer. Travaux Géophysiques, 27, 20-21.

Channell, J.E.T., Hodell, D.A., Margari, V., Skinner, L.C., Tzedakis, P.C., and Kesler, M.S., 2013. Biogenic magnetite, detrital hematite, and relative paleointensity in Quaternary 
sediments from the Southwest Iberian Margin. Earth and Planetary Science Letters, 376, 99-109.

Channell, J.E.T., Mazaud, A., Sullivan, P., Turner, S. and Raymo, M.E., 2002. Geomagnetic excursions and paleointensities in the Matuyama Chron at Ocean Drilling Program Sites 983 and 984 (Iceland Basin). Journal of Geophysical Research: Solid Earth (1978-2012), 107(B6), EPM 1-1.

Charola, A.E., Pühringer, J. and Steiger, M., 2007. Gypsum: a review of its role in the deterioration of building materials. Environmental geology, 52(2), 339-352.

Clement, A.C., Seager, R. and Cane, M., 1999. Orbital controls on the El Nino/Southern Oscillation and the tropical climate. Paleoceanography, 14(4), 441-456.

Cohen, A.S., 2003. Paleolimnology: the history and evolution of lake systems. Oxford University Press.

Collins, L.G., Hounslow, M.W., Allen, C.S., Hodgson, D.A., Pike, J., and Karloukovski, V.V., 2012. Palaeomagnetic and biostratigraphic dating of marine sediments from the Scotia Sea, Antarctica: First identification of the Laschamp excursion in the Southern Ocean. Quaternary Geochronology, 7, 67-75.

Cristini, L., Grosfeld, K., Butzin, M. and Lohmann, G., 2012. Influence of the opening of the Drake Passage on the Cenozoic Antarctic Ice Sheet: a modeling approach. Palaeogeography, Palaeoclimatology, Palaeoecology, 339, 66-73.

Croudace, I.W., Rindby, A. and Rothwell, R.G., 2006. ITRAX: description and evaluation of a new multi-function X-ray core scanner. Geological Society, London, Special Publications, 267(1), 51.

Cumming, B.F. and Smol, J.P., 1993. Development of diatom-based salinity models for paleoclimatic research from lakes in British Columbia (Canada). Twelfth International Diatom Symposium. Springer Netherlands, Dordrecht, pp. 179-196.

Cuven, S., Francus, P. and Lamoureux, S.F., 2010. Estimation of grain size variability with micro X-ray fluorescence in laminated lacustrine sediments, Cape Bounty, Canadian High Arctic. Journal of Paleolimnology, 44(3), 803-817.

De Porras, M., Maldonado, A., De Pol-Holz, R., Latorre, C. and Betancourt, J.L., 2017. Late Quaternary environmental dynamics in the Atacama Desert reconstructed from rodent midden pollen records. Journal of Quaternary Science, 32(6), 665-684.

Díaz, F.P., Latorre, C., Maldonado, A., Quade, J. and Betancourt, J.L., 2012. Rodent middens reveal episodic, long-distance plant colonizations across the hyperarid Atacama Desert over the last 34,000 years. Journal of Biogeography, 39(3), 510-525.

Dunai, T.J., López, G.A.G. and Juez-Larré, J., 2005. Oligocene-Miocene age of aridity in the Atacama Desert revealed by exposure dating of erosion-sensitive landforms. Geology, 33(4), 321-324.

Durcan, J.A., King, G.E. and Duller, G.A.T., 2015. DRAC: Dose Rate and Age Calculator for trapped charge dating. Quaternary Geochronology, 28, 54-61.

Dypvik, H. and Harris, N.B., 2001. Geochemical facies analysis of fine-grained siliciclastics using $\mathrm{Th} / \mathrm{U}, \mathrm{Zr} / \mathrm{Rb}$ and $(\mathrm{Zr}+\mathrm{Rb}) / \mathrm{Sr}$ ratios. Chemical Geology, 181(1), 131-146.

Ericksen, G.E., 1981. Geology and origin of the Chilean nitrate deposits. 1188.

Evenstar, L., Mather, A.E., Hartley, A.J., Stuart, F.M., Sparks, R.S.J., and Cooper, F.J., 2017. Geomorphology on geologic timescales: Evolution of the late Cenozoic Pacific paleosurface in Northern Chile and Southern Peru. Earth-Science Reviews, 171, 127.

Folk, R.L. and Ward, W.C., 1957. Brazos River bar [Texas]; a study in the significance of grain size parameters. Journal of Sedimentary Research, 27(1), 3-26.

Fornari, M., Risacher, F. and Féraud, G., 2001. Dating of paleolakes in the central Altiplano of Bolivia. Palaeogeography, Palaeoclimatology, Palaeoecology, 172(3), 269-282.

Fralick, P.W. and Kronberg, B.I., 1997. Geochemical discrimination of clastic sedimentary rock sources. Sedimentary Geology, 113(1), 111-124.

Francke, A., Wagner, B., Just, J., Leicher, N., Gromig, R., Baumgarten, H., Vogel, H., Lacey, J.H., Sadori, L., Wonik, T. and Leng, M.J., 2016. Sedimentological processes and environmental variability at Lake Ohrid (Macedonia, Albania) between $637 \mathrm{ka}$ and the present. Biogeosciences, 13(4), 1179-1196. 
Frenguelli, J., 1928. Diatomee fossili delle conche saline del deserto cileno-boliviano.

Frenguelli, J., 1936. Diatomeas de la caliza de la cuenca de Calama en el Desierto de Atacama (Chile). Universidad Nacional de La Plata, Instituto del Museo.

Fritz, S.C., Baker, P.A., Lowenstein, T.K., Seltzer, G.O., Rigsby, C.A., Dwyer, G.S., Tapia, P.M., Arnold, K.K., Ku, The-Lung and Luo, S., 2004. Hydrologic variation during the last 170,000 years in the southern hemisphere tropics of South America. Quaternary Research, 61(1), 95-104.

Galbraith, R.F., Roberts, R.G., Laslett, G.M., Yoshida, H. and Olley, J.M., 1999. Optical Dating of Single and Multiple Grains of Quartz from Jinmium Rock Shelter, Northern Australia: Part I, Experimental Design and Statistical Models. Archaeometry, 41(2), 339-364.

Galewsky, J., and Samuels-Crow, K., 2015. Summertime Moisture Transport to the Southern South American Altiplano: Constraints from In Situ Measurements of Water Vapor Isotopic Composition. Journal of Climate, 28(7), 2635-2649.

Garreaud, R., Vuille, M. and Clement, A.C., 2003. The climate of the Altiplano: observed current conditions and mechanisms of past changes. Palaeogeography, Palaeoclimatology, Palaeoecology, 194(1), 5-22.

Garreaud, R.D., Molina, A. and Farias, M., 2010. Andean uplift, ocean cooling and Atacama hyperaridity: A climate modeling perspective. Earth and Planetary Science Letters, 292(1), 39-50.

Garreaud, R.D., Vuille, M., Compagnucci, R. and Marengo, J., 2009. Present-day South American climate. Palaeogeography, Palaeoclimatology, Palaeoecology, 281(3), 180195.

Grosjean, M., Cartajena, I., Geyh, M.A. and Nuñez, L., 2003. From proxy data to paleoclimate interpretation: the mid-Holocene paradox of the Atacama Desert, northern Chile. Palaeogeography, Palaeoclimatology, Palaeoecology, 194(1), 247258.

Haberzettl, T., Corbella, H., Fey, M., Janssen, S., Lücke, A., Mayr, C., Ohlendorf, C., Schäbitz, F., Schleser, G.H., Wille, M., Wulf, S. and Zolitscha, B., 2007. Lateglacial and Holocene wet-dry cycles in southern Patagonia: chronology, sedimentology and geochemistry of a lacustrine record from Laguna Potrok Aike, Argentina. The Holocene, 17(3), 297-310.

Hartley, A.J. and Chong, G., 2002. Late Pliocene age for the Atacama Desert: Implications for the desertification of western South America. Geology, 30(1), 43-46.

Hogg, A.G., Hua, Q., Blackwell, P.G., Niu, M., Buck, C.E., Guilderson, T.P., Heaton, T., Palmer, J.G., Reimer, P.J., Reimer, R.W., Turney, C.S.M. and Zimmerman, S.R.H., 2016. SHCal13 Southern Hemisphere Calibration, 0-50,000 Years cal BP. Radiocarbon, 55(4), 1889-1903.

Houston, J., 2006a. Evaporation in the Atacama Desert: An empirical study of spatiotemporal variations and their causes. Journal of Hydrology, 330(3), 402-412.

Houston, J., 2006b. Variability of precipitation in the Atacama Desert: its causes and hydrological impact. International Journal of Climatology, 26(15), 2181-2198.

Houston, J. and Hartley, A.J., 2003. The central Andean west-slope rainshadow and its potential contribution to the origin of hyper-aridity in the Atacama Desert. International Journal of Climatology, 23(12), 1453-1464.

Huntley, D.J. and Lamothe, M., 2001. Ubiquity of anomalous fading in K-feldspars and the measurement and correction for it in optical dating. Canadian Journal of Earth Sciences, 38(7), 1093-1106.

Jordan, T. et al., 2015. Hydrological and geomorphological consequences of the extreme precipitation event of 24-26 March 2015, Chile, XIV Congreso Geologico Chileno (La Serena).

Jordan, T.E., Kirk-Lawlor, N.E., Blanco, N.P., Rech, J.A. and Cosentino, N.J., 2014. Landscape modification in response to repeated onset of hyperarid paleoclimate states since $14 \mathrm{Ma}$, Atacama Desert, Chile. GSA Bulletin, 126(7-8), 1016-1046.

Kim, J.-H., Schneider, R.R., Hebbeln, D., Müller, P.J. and Wefer, G., 2002. Last deglacial sea-surface temperature evolution in the Southeast Pacific compared to climate 
changes on the South American continent. Quaternary Science Reviews, 21(18), 2085-2097.

King, J.W., Banerjee, S.K. and Marvin, J., 1983. A new rock-magnetic approach to selecting sediments for geomagnetic paleointensity studies: Application to paleointensity for the last 4000 years. Journal of Geophysical Research: Solid Earth, 88(B7), 5911-5921.

Kirschvink, J.L., 1980. The least-squares line and plane and the analysis of palaeomagnetic data. Geophysical Journal International, 62(3), 699-718.

Krammer, K. and Lange-Bertalot, H., 1986. 1991. Bacillariophyceae. G. Fischer Verlag, Stuttgart.

Kylander, M.E., Ampel, L., Wohlfarth, B. and Veres, D., 2011. High-resolution X-ray fluorescence core scanning analysis of Les Echets (France) sedimentary sequence: new insights from chemical proxies. Journal of Quaternary Science, 26(1), 109-117.

Labbé, N., García, M., Simicic, Y., Contreras-Reyes, E., Charrier, R., De Pascale, G., and Arriagada, C., 2018. Sediment fill geometry and structural control of the Pampa del Tamarugal basin, northern Chile. Bulletin, 131(1-2), 155-174.

Lamy, F., Hebbeln, D. and Wefer, G., 1998. Late Quaternary precessional cycles of terrigenous sediment input off the Norte Chico, Chile (27.5 S) and palaeoclimatic implications. Palaeogeography, Palaeoclimatology, Palaeoecology, 141(3), 233-251.

Latorre, C., Betancourt, J.L., Rylander, K.A. and Quade, J., 2002. Vegetation invasions into absolute desert: A 45,000 yr rodent midden record from the Calama-Salar de Atacama basins, northern Chile (lat 22-24 S). Geological Society of America Bulletin, 114(3), 349-366.

Leicher, N., Zanchetta, G., Sulpizio, R., Giaccio, B., Wagner, B., Nomade, S., Francke, A. and Del Carlo, P., 2016. First tephrostratigraphic results of the DEEP site record from Lake Ohrid (Macedonia and Albania). Biogeosciences, 13, 2151-2178 pp.

Lisiecki, L.E. and Raymo, M.E., 2005. A Pliocene-Pleistocene stack of 57 globally distributed benthic $\delta 180$ records. Paleoceanography, 20(1).

Lund, S., Stoner, J.S., Channell, J.E.T. and Acton, G., 2006. A summary of Brunhes paleomagnetic field variability recorded in Ocean Drilling Program cores. Physics of the Earth and Planetary Interiors, 156(3), 194-204.

Maldonado, A., Betancourt, J.L., Latorre, C. and Villagran, C., 2005. Pollen analyses from a 50 000-yr rodent midden series in the southern Atacama Desert (25 30' S). Journal of Quaternary Science: Published for the Quaternary Research Association, 20(5), 493-507.

Marin, J.C., and Barrett B.S., 2017. Seasonal and intraseasonal variability of precipitable water vapour in the Chajnantor plateau, Chile. International Journal of Climatology, 37, 958-971.

May, S.M., Meine, L., Hoffmeister, D., Brill, D., Medialdea, A., Wennrich, V., Gröbner, M., Schulte, P., Steininger, F., Deprez, M., De Kock, T. and Bubenzer, O., this issue. Origin and timing of past hillslope activity in the hyper-arid core of the Atacama Desert - the formation of fine sediment lobes along the Chuculay Fault System, northern Chile. Global and Planetary Change.

Medialdea, A., May, S.M., Brill, D., King, G., Ritter, B., Wennrich, V., Bartz, M., Zander, A., Hurtado, S., Kuiper, K., Hoffmeister, D., Schulte, P., Gröbner, M., Opitz, S., Brückner, $\mathrm{H}$. and Bubenzer, O., this issue. Identification of humid periods in the Atacama Desert through hillslope activity established by infrared stimulated luminescence (IRSL) dating. Global and Planetary Change.

Melchiorre, E.B., Sickman, J.O., Talyn, B.C. and Noblet, J., 2018. Isotope stratigraphy: Insights on paleoclimate and formation of nitrate deposits in the Atacama Desert, Chile. Journal of Arid Environments, 148, 45-53.

Mujica, M.I., Latorre, C., Maldonado, A., González-Silvestre, L., Pinto, R., de Pol-Holz, R., and Santoro, C.M., 2015. Late Quaternary climate change, relict populations and present-day refugia in the northern Atacama Desert: a case study from Quebrada La Higuera $\left(18^{\circ} \mathrm{S}\right)$. Journal of Biogeography, 42(1), 76-88. 
Nowaczyk, N.R., Arz, H.W., Frank, U., Kind, J. and Plessen, B., 2012. Dynamics of the Laschamp geomagnetic excursion from Black Sea sediments. Earth and Planetary Science Letters, 351-352, 54-69.

Nowaczyk, N.R. and Baumann, M., 1992. Combined high-resolution magnetostratigraphy and nannofossil biostratigraphy for late Quaternary Arctic Ocean sediments. Deep Sea Research Part A. Oceanographic Research Papers, 39(2, Part 1), S567-S601.

Nowaczyk, N.R. and Frederichs, T.W., 1999. Geomagnetic events and relative palaeointensity variations during the past $300 \mathrm{ka}$ as recorded in Kolbeinsey Ridge sediments, Iceland Sea: indication for a strongly variable geomagnetic field. International Journal of Earth Sciences, 88(1), 116-131.

Nunnery, J.A., Fritz, S.C., Baker, P.A. and Salenbien, W., 2018. Lake-level variability in Salar de Coipasa, Bolivia during the past 40,000 yr. Quaternary Research, 91(2), 881-891.

Paillard, D., Labeyrie, L. and Yiou, P., 1996. AnalySeries 1.0: a Macintosh software for the analysis of geophysical time-series. Eos, 77, 379.

Pfeiffer, M., Latorre, C., Santoro, C.M., Gayo, E.M., Rojas, R., Carrevedo, M.L., McRostie, V.B., Finstad, K.M., Heimsath, A., Jungers, M.C., De Pol-Holz, R. and Amundson, R., 2018. Chronology, stratigraphy and hydrological modelling of extensive wetlands and paleolakes in the hyperarid core of the Atacama Desert during the late quaternary. Quaternary Science Reviews, 197, 224-245.

Pinto, R., Barria, I. and Marquet, P.A., 2006. Geographical distribution of Tillandsia lomas in the Atacama Desert, northern Chile. Journal of arid environments, 65(4), 543-552.

Pizarro, J. and Montecinos, A., 2000. Cutoff cyclones off the subtropical coast of Chile. Preprints, Sixth Int. Conf. on Southern Hemisphere Meteorology and Oceanography, pp. 278-279.

Placzek, C., Quade, J. and Patchett, P.J., 2006. Geochronology and stratigraphy of late Pleistocene lake cycles on the southern Bolivian Altiplano: implications for causes of tropical climate change. Geological Society of America Bulletin, 118(5-6), 515-532.

Placzek, C.J., Quade, J. and Patchett, P.J., 2013. A 130ka reconstruction of rainfall on the Bolivian Altiplano. Earth and Planetary Science Letters, 363, 97-108.

Prospero, J.M., Ginoux, P., Torres, O., Nicholson, S.E. and Gill, T.E., 2002. Environmental characterization of global sources of atmospheric soil dust identified with the Nimbus 7 Total Ozone Mapping Spectrometer (TOMS) absorbing aerosol product. Reviews of geophysics, 40(1), 2-1-2-31.

Quade, J., Rech, J.A., Betancourt, J.L., Latorre, C., Quade, B., Rylander, K.A. and Fisher, T., 2008. Paleowetlands and regional climate change in the central Atacama Desert, northern Chile. Quaternary Research, 69(3), 343-360.

Quade, J., Rech, J.A., Latorre, C., Betancourt, J.L., Gleeson, E. and Kalin, M.T., 2007. Soils at the hyperarid margin: The isotopic composition of soil carbonate from the Atacama Desert, Northern Chile. Geochimica et Cosmochimica Acta, 71(15), 3772-3795.

Rech, J.A., Currie, B.S., Shullenberger, E.D., Dunagan, S.P., Jordan, T.E., Blanco, N., Tomlinson, A.J., Rowe, H.D. and Houston, J., 2010. Evidence for the development of the Andean rain shadow from a Neogene isotopic record in the Atacama Desert, Chile. Earth and Planetary Science Letters, 292(3), 371-382.

Rech, J.A., Quade, J. and Betancourt, J.L., 2002. Late Quaternary paleohydrology of the central Atacama Desert (lat 22-24 S), Chile. Geological Society of America Bulletin, 114(3), 334-348.

Reyers, M., Hamidi, M. and Shao, Y., 2019. Synoptic analysis and simulation of an unusual dust event over the Atacama Desert. Atmospheric Science Letters, e899.

Reyers, M. and Shao, Y., 2019. Cutoff Lows off the Coast of the Atacama Desert under Present Day Conditions and in the Last Glacial Maximum. Global and Planetary Change, 181, 102983.

Rincón-Martínez, D., Lamy, F., Contreras, S., Leduc, G., Bard, E., Saukel, C., Blanz, T., Mackensen, A. and Tiedemann, R., 2010. More humid interglacials in Ecuador during the past 500 kyr linked to latitudinal shifts of the equatorial front and the Intertropical Convergence Zone in the eastern tropical Pacific. Paleoceanography and Paleoclimatology, 25(2). 
Ritter, B., Stuart, F.M., Binnie, S.A., Gerdes, A., Wennrich, V. and Dunai, T.J., 2018. Neogene fluvial landscape evolution in the hyperarid core of the Atacama Desert. Scientific reports, 8(1), 13952.

Ritter, B., Wennrich, V., Medialdea, A., Brill, D., King, G., Schneiderwind, S., Niemann, K., Fernández-Galego, E., Diederich, J., Rolf, C., Bao, R., Melles, M. and Dunai, T.J., 2019. Climatic fluctuations in the hyperarid core of the Atacama Desert during the past $215 \mathrm{ka}$. Scientific reports, 9(1), 5270.

Rumrich, U., Lange-Bertalot, H. and Rumrich, M., 2000. Diatomeen der Anden: von Venezuela bis Patagonien/Feuerland und zwei weitere Beiträge. Icono-gr aphia Diatomológica: Vol. 9. Koeltz Scientific Books Koenigstein.

Rutllant, J., Muñoz, R. and Garreaud, R., 2013. Meteorological observations on the northern Chilean coast during VOCALS-REx. Atmospheric Chemistry and Physics, 13(6), 3409-3422.

Rutllant, J.A., Fuenzalida, H. and Aceituno, P., 2003. Climate dynamics along the arid northern coast of Chile: The 1997-1998 Dinámica del Clima de la Región de Antofagasta (DICLIMA) experiment. Journal of Geophysical Research: Atmospheres (1984-2012), 108(D17).

Sáez, A., Cabrera, L., Garcés, M., van den Bogaard, P., Jensen, A. and Gimeno, D., 2012. The stratigraphic record of changing hyperaridity in the Atacama desert over the last $10 \mathrm{Ma}$. Earth and Planetary Science Letters, 355, 32-38.

Sáez, A., Godfrey, L.V., Herrera, C., Chong, G. and Pueyo, J.J., 2016. Timing of wet episodes in Atacama Desert over the last $15 \mathrm{ka}$. The Groundwater Discharge Deposits (GWD) from Domeyko Range at $25^{\circ} \mathrm{S}$. Quaternary Science Reviews, 145 , 82-93.

Sancetta, C., 1979. Use of semiquantitative microfossil data for paleoceanography. Geology, 7(2), 88-92.

Saukel, C., Lamy, F., Stuut, J.-B.W., Tiedemann, R. and Vogt, C., 2011. Distribution and provenance of wind-blown SE Pacific surface sediments. Marine Geology, 280(1-4), 130-142.

Schulz, N., Aceituno, P. and Richter, M., 2011. Phytogeographic divisions, climate change and plant dieback along the coastal desert of northern Chile. Erdkunde, 169-187.

Servant Vildary, S., 1978. Les Diatomées des Sédiments superficiels d'un lac salé, Chloruré, sulfaté sodique de L'Altiplano Bolivien, le lac Poopó. Cahiers ORSTOM. Série Géologie, 10(1), 79-90.

Servant Vildary, S. and Blanco, M., 1984. Les diatomées fluvio-lacustres plio-pléistocènes de la Formation Charaña (Cordillère occidentale des Andes, Bolivie). Cahiers ORSTOM. Série Géologie, 14(1), 55-102.

Servant-Vildary, S. and Mello e Sousa, S., 1993. Palaeohydrology of the Quaternary saline Lake Ballivian (southern Bolivian Altiplano) based on diatom studies. International Journal of Salt Lake Research, 2(1), 69-85.

Servant-Vildary, S. and Roux, M., 1990. Multivariate analysis of diatoms and water chemistry in Bolivian saline lakes. Saline Lakes. Springer Netherlands, Dordrecht, pp. 267-290.

Sillitoe, R.H. and McKee, E.H., 1996. Age of supergene oxidation and enrichment in the Chilean porphyry copper province. Economic Geology, 91(1), 164-179.

Stoner, J.S., Laj, C., Channell, J.E.T. and Kissel, C., 2002. South Atlantic and North Atlantic geomagnetic paleointensity stacks $(0-80 \mathrm{ka})$ : implications for inter-hemispheric correlation. Quaternary Science Reviews, 21(10), 1141-1151.

Stuiver, M., Reimer, P. and Reimer, R., 2017. Calib 7.1 [www program].

Stuut, J.-B.W. and Lamy, F., 2004. Climate variability at the southern boundaries of the Namib (southwestern Africa) and Atacama (northern Chile) coastal deserts during the last 120,000 yr. Quaternary Research, 62(3), 301-309.

Sun, Q., Wang, H. and Zamanian, K., 2019. Radiocarbon age discrepancies between the carbonate cement and the root relics of rhizoliths from the Badain Jaran and the Tengeri deserts, Northwest China. CATENA, 180, 263-270. 
Sylvestre, F., Servant-Vildary, S. and Roux, M., 2001. Diatom-based ionic concentration and salinity models from the south Bolivian Altiplano $\left(15-23^{\circ} \mathrm{S}\right.$. Journal of

Paleolimnology, 25(3), 279-295.

Takahashi, K. and Battisti, D.S., 2007. Processes Controlling the Mean Tropical Pacific Precipitation Pattern. Part I: The Andes and the Eastern Pacific ITCZ. Journal of Climate, 20(14), 3434-3451.

Tauxe, L., 1993. Sedimentary records of relative paleointensity of the geomagnetic field: Theory and practice. Reviews of Geophysics, 31(3), 319-354.

Taylor, S.R., 1965. The application of trace element data to problems in petrology. Physics and Chemistry of the Earth, 6, 133-213.

Thiel, M., Macaya, E.C., Acuna, E., Arntz, W.E., Bastias, H., Brokordt, K., Camus, P.A., Castilla, J.C., Castro, L.R., Cortés, M., Dumont, C.P., Escribano, R., Fernandez, M., Gajardo, J.A., Gaymer, C.F., Gomez, I., González, A.E., González, H.E., Haye, P.A., Illanes, J.-E., Iriarte, J.L., Lancellotti, D.A., Luna-Jorquera, G., Luxoro, C., Manriquez, P.H., Marín, V., Muñoz, P., Navarrete, S.A., Perez, E., Poulin, E., Sellanes, J., Sepúlveda, H.H., Stotz, W., Tala, F., Thomas, A., Vargas, C.A., Vasquez, J.A. and Vega, J.M., 2007. The Humboldt Current System of northern and central Chile: oceanographic processes, ecological interactions and socioeconomic feedback. Oceanography and marine biology: an annual review.

Van Dam, H., Mertens, A. and Sinkeldam, J., 1994. A coded checklist and ecological indicator values of freshwater diatoms from The Netherlands. Netherland Journal of Aquatic Ecology, 28(1), 117-133.

Vargas, G., Rutllant, J. and Ortlieb, L., 2006. ENSO tropical-extratropical climate teleconnections and mechanisms for Holocene debris flows along the hyperarid coast of western South America (17-24 S). Earth and Planetary Science Letters, 249(3-4), 467-483.

Vásquez, P. and Sepúlveda, F.A., 2013. Cartas lquique y Pozo Almonte, Región de Tarapacá. mapa escala 1:100.000. Servicio Nacional de Geología y Minería, Carta Geológica de Chile, Serie Geología Básica 162-163.

Vogel, H., Wagner, B., Zanchetta, G., Sulpizio, R. and Rosén, P., 2010. A paleoclimate record with tephrochronological age control for the last glacial-interglacial cycle from Lake Ohrid, Albania and Macedonia. Journal of Paleolimnology, 44(1), 295-310.

Voigt, C., Klipsch, S., Herwartz, D., Chong, G. and Staubwasser, M., this issue. The spatial distribution of soluble salts in the surface soil of the Atacama Desert and their relationship to hyperaridity. Global and Planetary Change.

Vos, P.C. and de Wolf, H., 1993. Diatoms as a tool for reconstructing sedimentary environments in coastal wetlands; methodological aspects. Hydrobiologia, 269(1), 285-296.

Vuille, M., 1999. Atmospheric circulation over the Bolivian Altiplano during dry and wet periods and extreme phases of the Southern Oscillation. International Journal of Climatology, 19(14), 1579-1600.

Walk, J., Stauch, G., Reyers, M., Vásquez, P., Sepúlveda, F.A., Bartz, M., Hoffmeister, D., Brückner, H. and Lehmkuhl, F., 2019. Gradients in climate, geology, and topography affecting coastal alluvial fan morphodynamics in hyperarid regions - the Atacama perspective. Global and Planetary Change, 102994.

Wennrich, V., Minyuk, P.S., Borkhodoev, V., Francke, A., Ritter, B., Nowaczyk, N.R., Sauerbrey, M.A., Brigham-Grette, J. and Melles, M., 2014. Pliocene to Pleistocene climate and environmental history of Lake El'gygytgyn, Far East Russian Arctic, based on high-resolution inorganic geochemistry data.

Wilcox, A.C., Escauriaza, C., Agredano, R., Mignot, E., Zuazo, V., Otárola, S., Castro, L., Gironás, J., Cienfuegos, R. and Mao, L., 2016. An integrated analysis of the March 2015 Atacama floods. Geophysical Research Letters, 43(15), 8035-8043. 

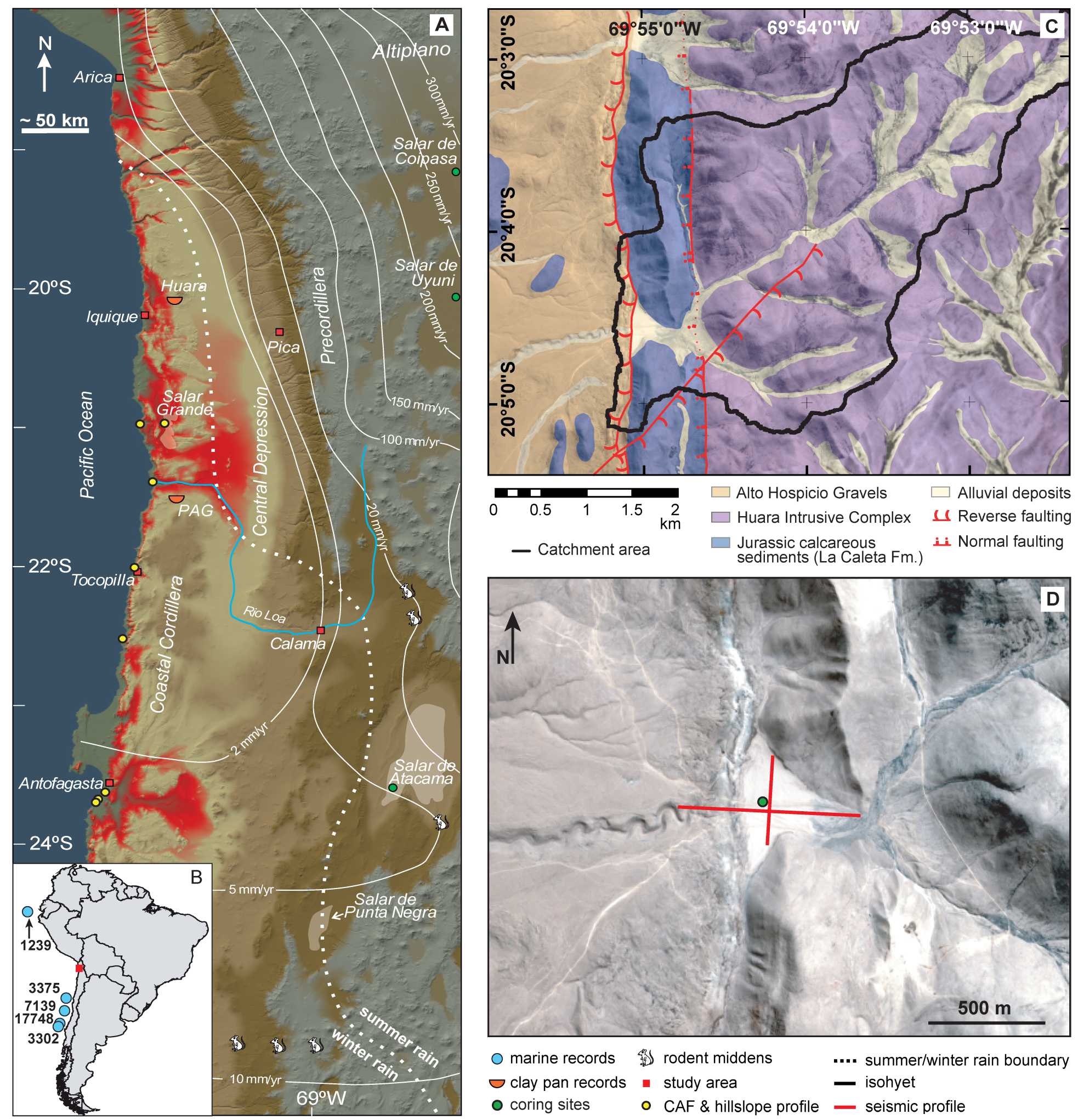

O marine records 5 rodent middens $\quad$.... summer/winter rain boundary

$\checkmark$ clay pan records a study area - isohyet

o coring sites $\quad$ CAF \& hillslope profile — seismic profile 

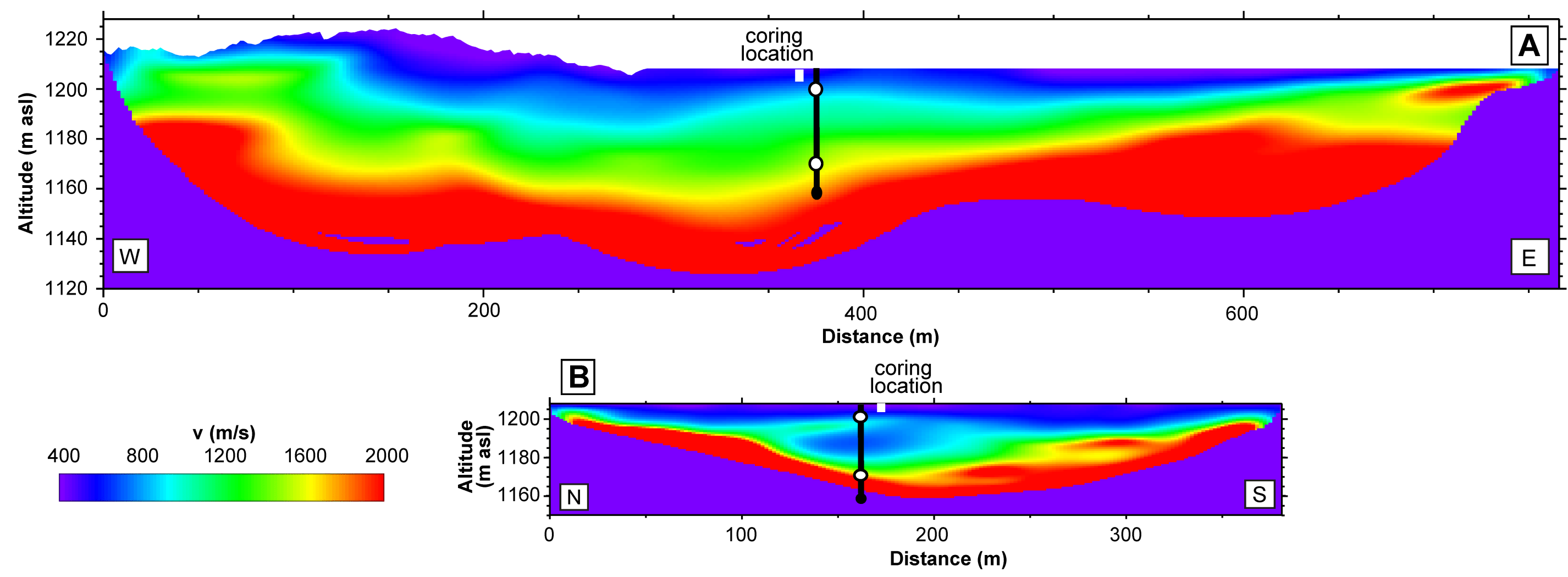

Figure 2 (Diederich et al., 2020) 


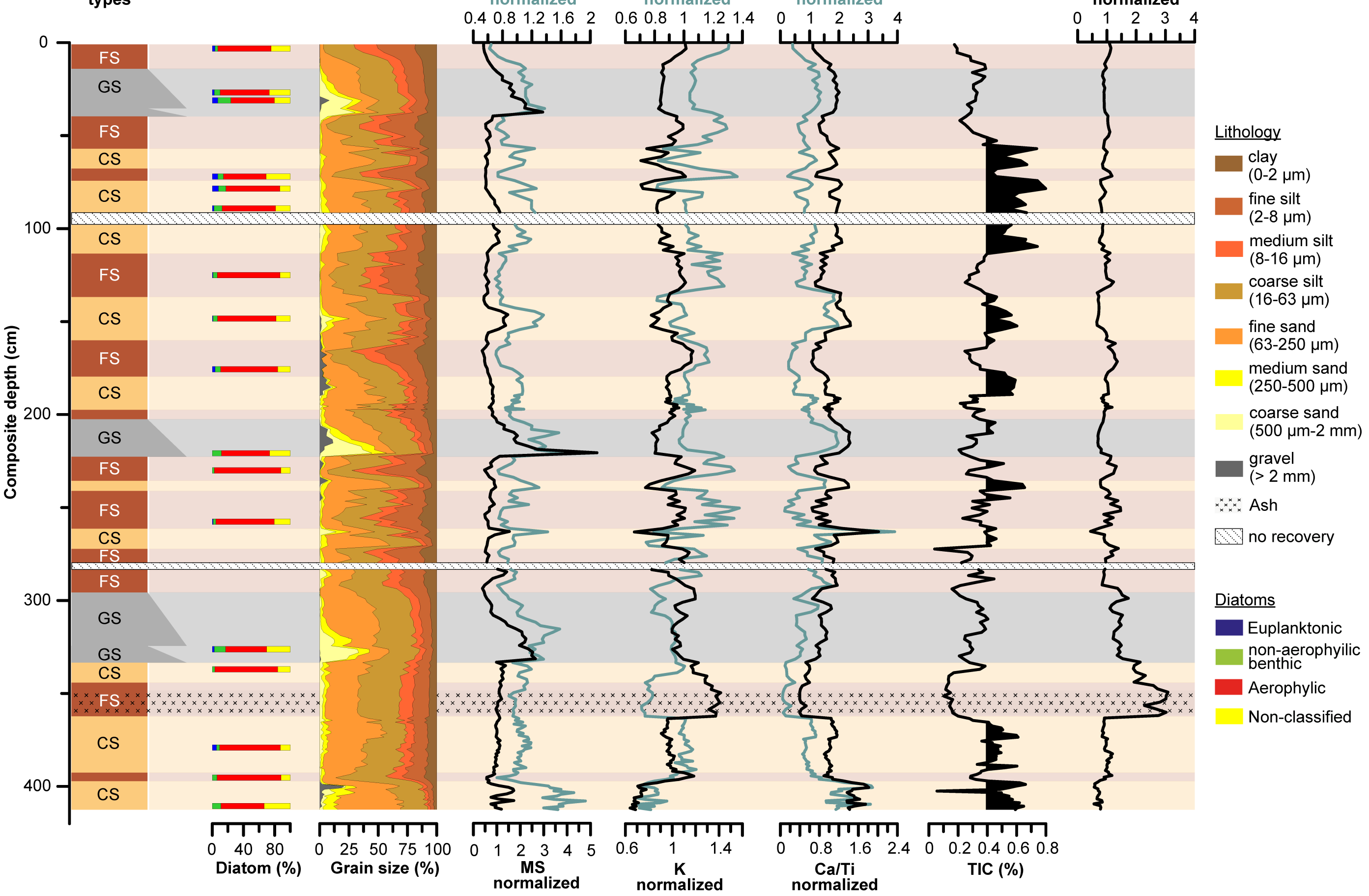

Figure 3 (Diederich et al., 2020) 


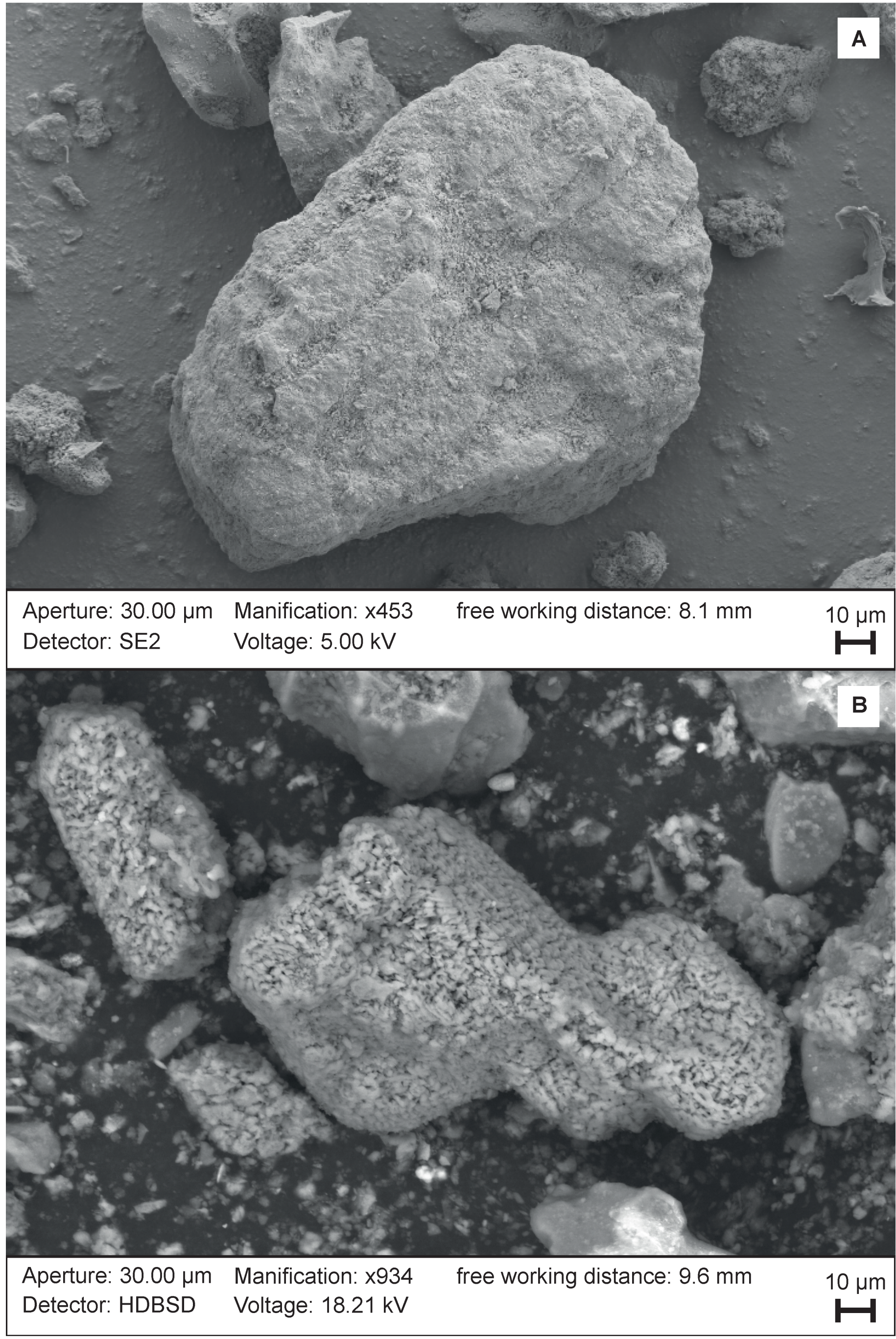

Figure 4 (Diederich et al., 2020) 


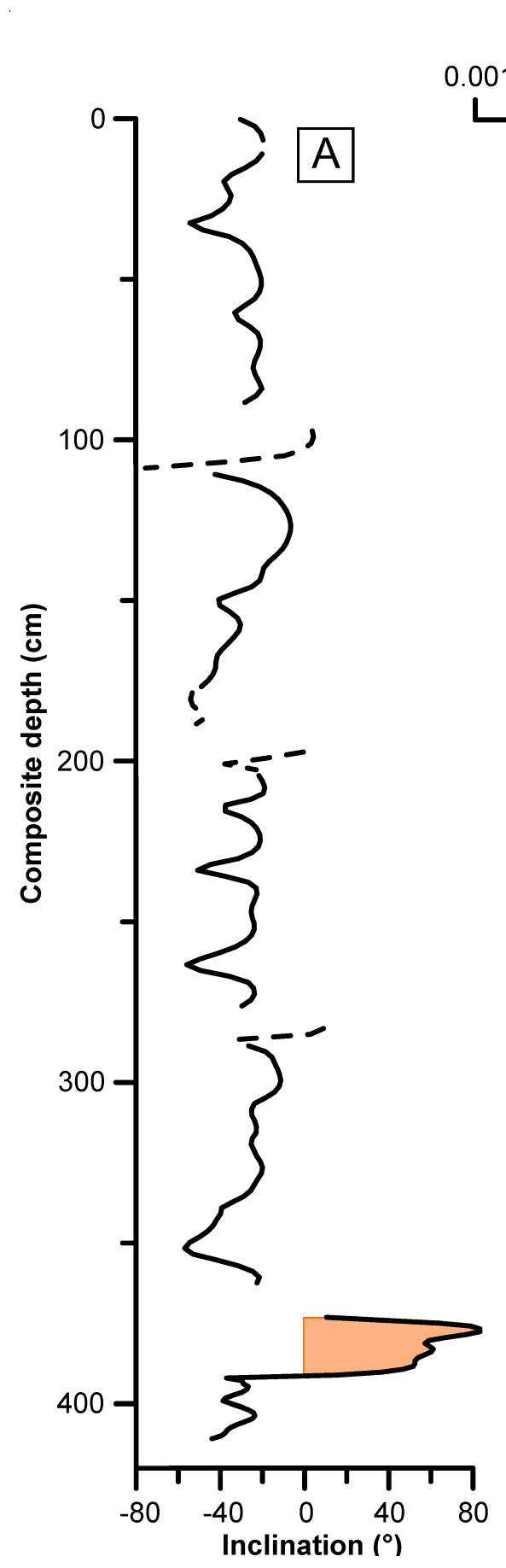

\section{RPI proxy}

Age

(ka)

"
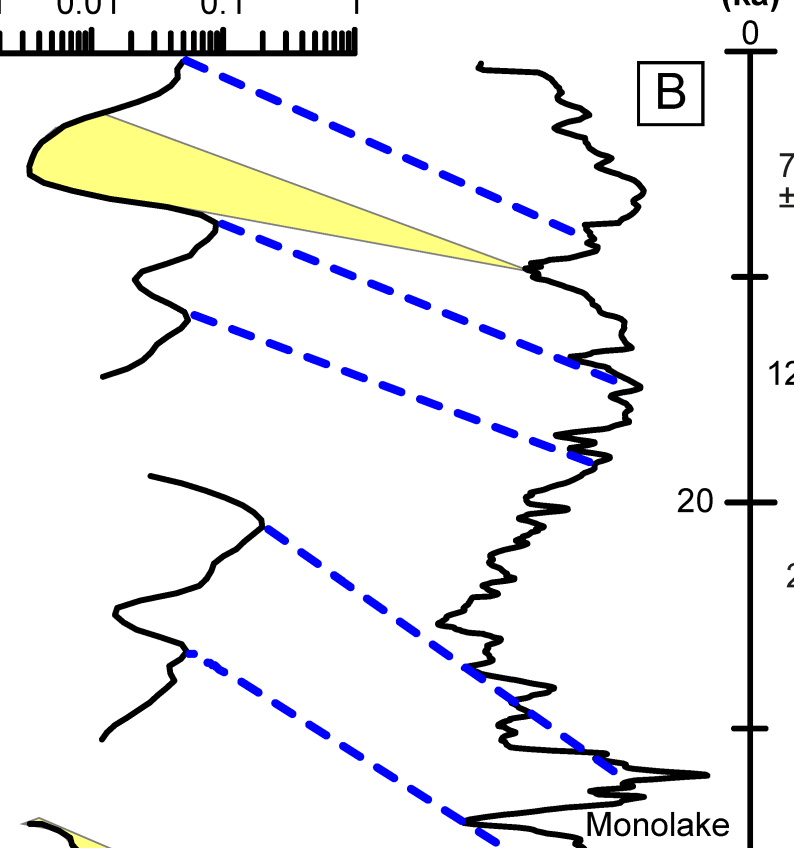

$19.3 \pm 1.4$

$22.1 \pm 0.2$

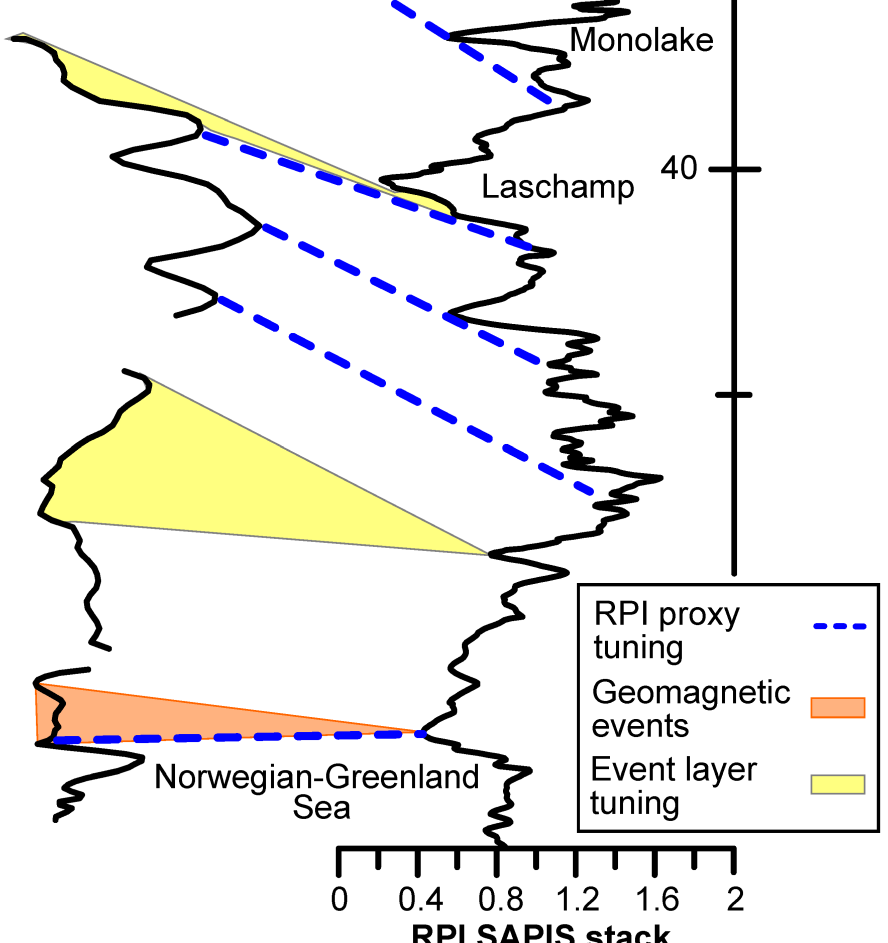

Depth $(\mathrm{cm})$

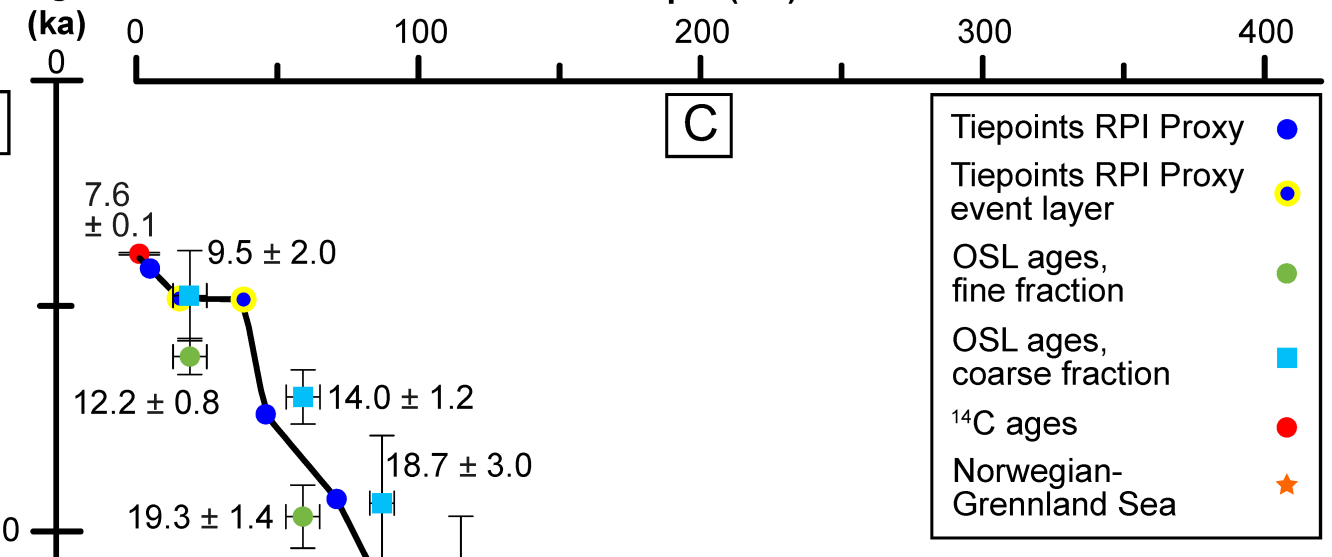

$+22.2 \pm 2.9$
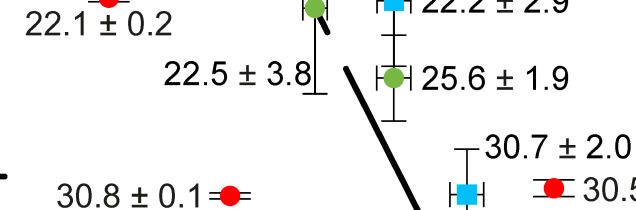

Grennland Sea

$34.4 \pm 0.3=$

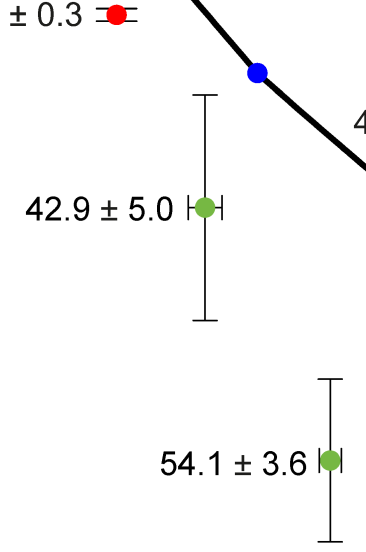

RPI SAPIS stack

Figure 5 (Diederich et al., 2020) 
Hyperarid core of the Atacama
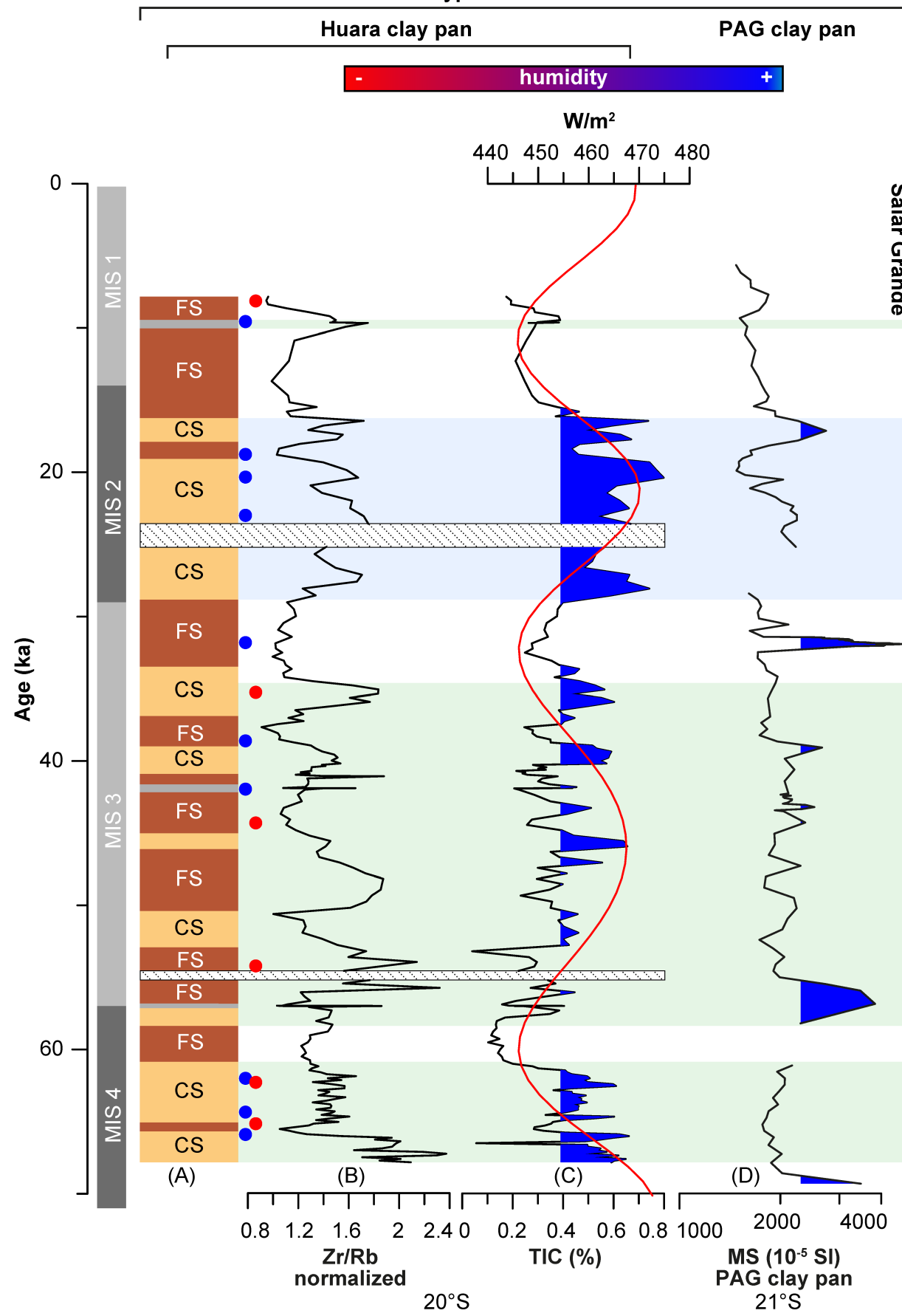

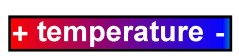

$$
\text { SST }\left({ }^{\circ} \mathrm{C}\right)
$$$$
\text { ODP 1239; } 0^{\circ} \mathrm{S}
$$$$
\begin{array}{llll}
26 & 25 & 24 & 23
\end{array}
$$
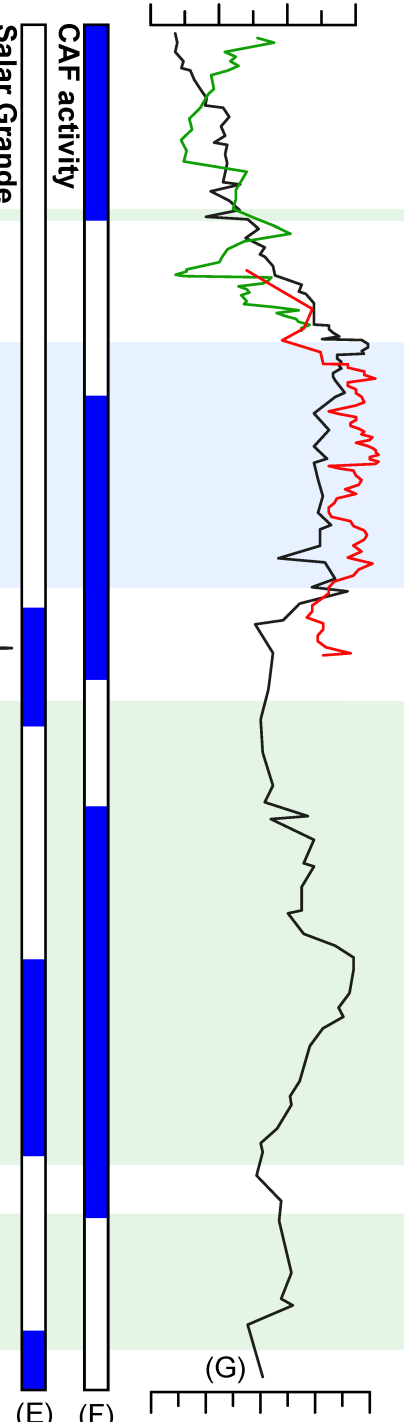

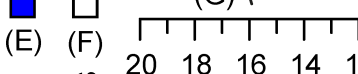

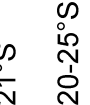

SST $\left({ }^{\circ} \mathrm{C}\right)$ $7748 / \mathrm{GeoB} 330$ $32^{\circ} \mathrm{S} ; 33^{\circ} \mathrm{S}$
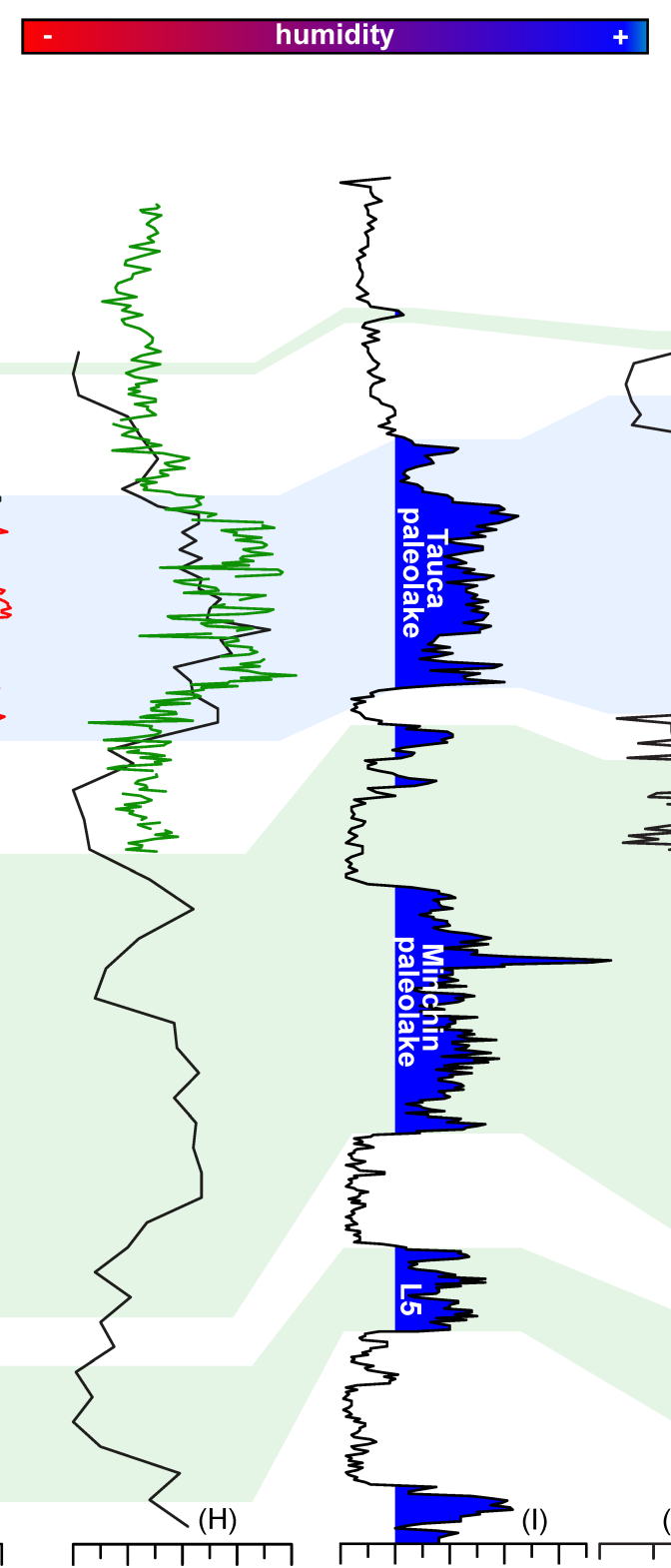

$\begin{array}{lllll}0 & 0.2 & 0.4 & 0.6 & 0.8\end{array}$

Humidity index

B3375/GeoB7139

$27^{\circ} \mathrm{S} ; 30^{\circ} \mathrm{S}$
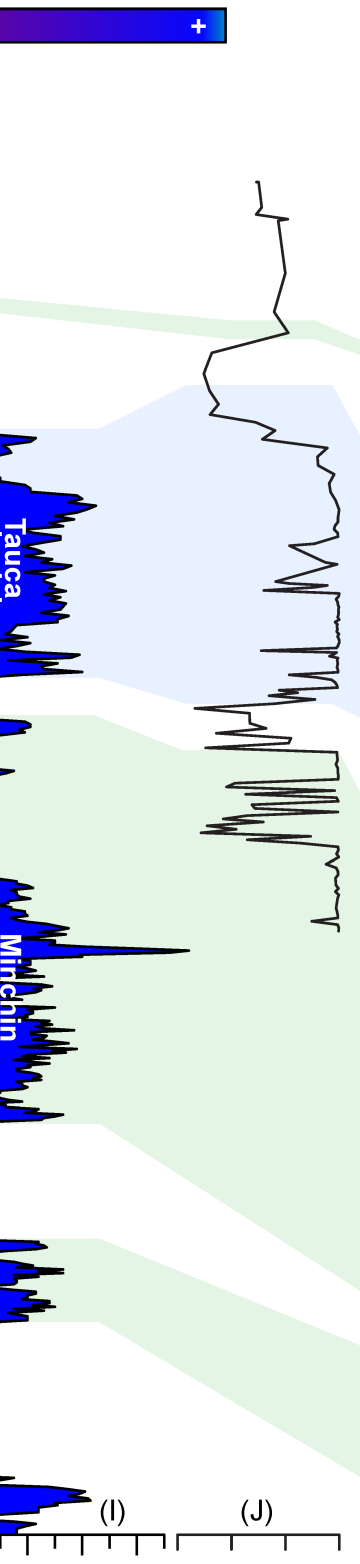

$\begin{array}{lllllll}40 & 60 & 80 & 4 & 3 & 2 & 0\end{array}$ NGR $\quad \mathrm{Ca}(\%)$ Salar Ca (\%) Salar
NGR Coipasa $20^{\circ} \mathrm{S} \quad 19^{\circ} \mathrm{S}$

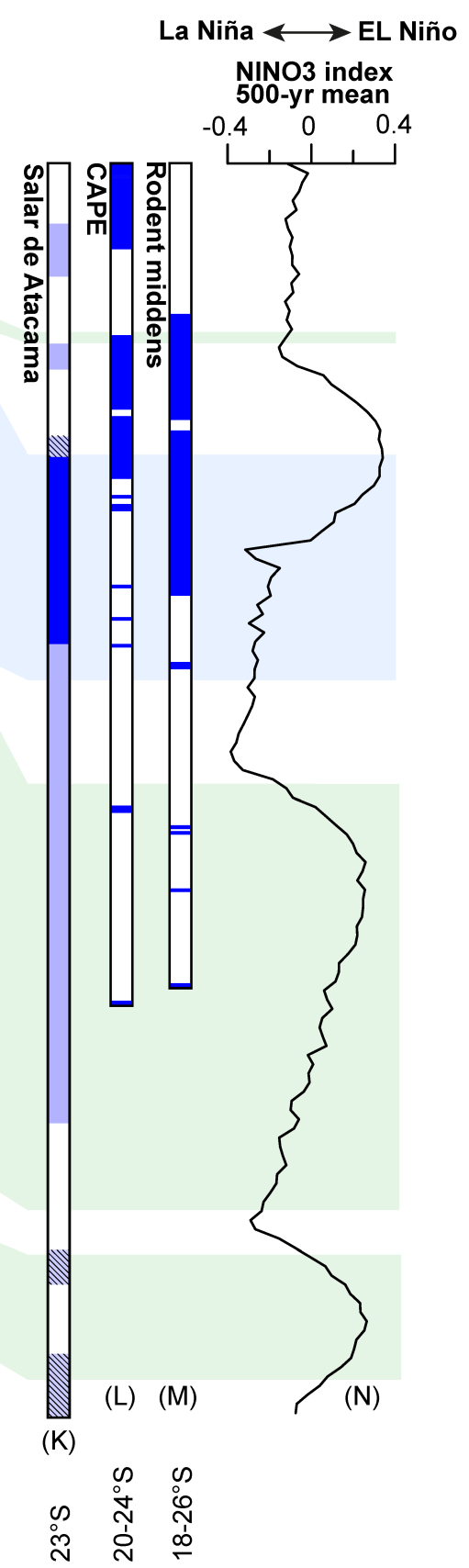

Figure 6 (Diederich et al., 2020) 